Proceedings of the Institution of
Civil Engineers
Structures and Buildings 162
June 2009 Issue SB3
Pages $169-182$
doi: $10.1680 /$ stbu.2009.162.3.169
Paper 800041
Received 13/05/2008
Accepted 27/II/2008
Keywords: buildings, structures \&
design/codes of practice \&
standards/seismic engineering
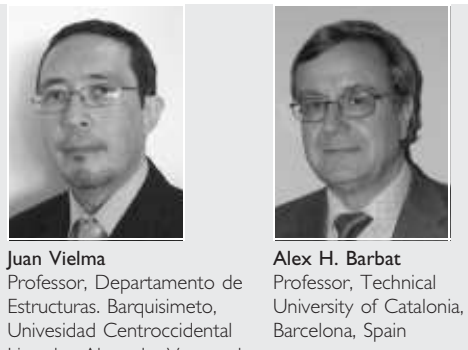

\title{
Seismic performance of waffled-slab floor buildings
}

\author{
J. Vielma MSc, PhD, A. H. Barbat PhD and S. Oller PhD
}

The codes used in seismic design of waffled-slab floors buildings (WSFB), such as the Spanish NCSE-02 earthquake-resistant design code, assign them restricted ductility, utilise linear structural analysis based on modal analysis, but also consider the structural ductility concept. Uncertainties arise whenever these codes are applied to the special case of buildings with waffled-slab floors, the ductility of which is doubtful. In many cases, during earthquakes, buildings with restricted ductility are unable to reach the ductility values assumed in the design process, although they may exhibit adequate values of overstrength. This paper therefore studies typical WSFB by applying static incremental non-linear analysis procedures (pushover analysis) in order to calculate their actual structural ductility and overstrength values. Fragility curves corresponding to different damage states and damage probability matrices are also calculated and compared with those of momentresisting frame buildings (MRFB) in order to obtain useful conclusions for earthquake resistant design. One of the most relevant conclusions of this article is that the use of a better confinement and of ductile steel can only improve the seismic behaviour of MRFB but not that of WSFB.

\section{INTRODUCTION}

Studies performed recently in areas of Spain with low-tomoderate seismic hazard ${ }^{1}$ reveal that seismic vulnerability is high in such areas and, consequently, that their seismic risk is significant. This is mainly owing to the typology of the existing buildings, most of them with unreinforced masonry structures, designed and built without the consideration of any earthquake-resistant criteria. ${ }^{2,3}$ Moreover, most of the existing reinforced concrete $(\mathrm{RC})$ buildings are not moment-resisting frames, but structures with waffled-slab floors. ${ }^{4}$ It therefore appears to be useful to perform more detailed studies of this typology of buildings in order to establish if it is reasonable to recommend their use in seismic areas.

The emergence of performance-based procedures for the design and retrofit of earthquake-resistant buildings ${ }^{5-7}$ has sparked research on the non-linear static response of buildings. ${ }^{8}$ Among the most studied structural typologies is that of the moment-resisting frame buildings (MRFB). ${ }^{9,}{ }^{10}$ However, the non-linear response of restricted ductility buildings, that is, buildings expressly designed to have low ductility, including columns-and-slabs RC buildings, has not been studied at large. ${ }^{11,12}$ These last classes of buildings are frequent in Spain and in other European countries (e.g. Turkey) or Latin America (e.g. Ecuador, Dominican Republic and Mexico), where their waffled-slab floor version is used. It is worth mentioning that the Uniform Building Code (UBC)- $97^{13}$ and International Building Code (IBC)-2003 ${ }^{14}$ codes, as well as the Eurocode $8,{ }^{15}$ do not make any reference to waffled-slab floors as possible structural elements to be used in the earthquake-resistant design of buildings.

Adequacy of the response of a structure to a given seismic threat can be evaluated, in a simplified way, through examination of two important non-linear response characteristics

(a) the maximum ductility value reached by such buildings during a strong ground motion

(b) the reduction factor applied to design spectrum ordinates in order to calculate the seismic design forces, this factor being closely related to the overstrength.

According to the Norma de Construction Sismorresistente (NCSE)-02 Spanish earthquake-resistant design code, ${ }^{16}$ waffled-slab floors buildings (WSFB) have restricted ductility values of two. This value is set based on the well-known premise that this structural typology has low capacity for energy dissipation. At the same time, apart from the UBC-97 and

IBC-2003, the Eurocode 8 and NCSE-02 Spanish code do not refer directly to overstrength values, which are very important for determining the response reduction factors. ${ }^{17,18}$

With these observations as a starting point, the main objective of this paper is to study the typical WSFB seismic behaviour by calculating their actual structural ductility and overstrength values, using an incremental non-linear static analysis procedure (pushover analysis). In this simplified analysis, lateral forces corresponding to the first vibration mode shape are gradually applied and global structural damage indexes are used to determine the ultimate drift values of the buildings. Drift values corresponding to the yielding point are obtained by using the idealised bilinear form of the capacity curve proposed by Park. ${ }^{19}$ The benefits of the ductility of the steel reinforcements and of the longitudinal and transversal 
confinements are also evaluated using the building pushover response.

With the objective of elucidating how structural typology and design have an influence on the global response of building structures, three buildings with different characteristics were designed and analysed. The first building has waffled-slab floors and has been designed with a reduction factor of two. The second building, has moment-resisting RC frames, it is designed according to the Instruccion de Hormigon Estructura $(\mathrm{EHE})^{20}$ and NCSE-02 Spanish codes, and has a ductility of four. Finally, the third building is also designed using momentresisting $\mathrm{RC}$ frames, but according to the American Concrete Institute (ACI) ${ }^{21}$ specifications in order to fulfil ductility requirements of eight. The capacity curve of the WSFB is compared with those of the two MRFB. Fragility curves and damage probability matrices are also obtained in order to compare the probability the WSFB and MRFB exceed different predefined damage states. Preliminary conclusions on the suitability of using WSFB in seismic areas are finally given.

\section{DESCRIPTION OF THE BUILDINGS STUDIED}

2.I. Building with waffled-slab floors

The WSFB slabs have ribs oriented in two orthogonal

directions and a solid thin RC layer in the upper face. The

configuration of the ribs generates square spaces on the lower
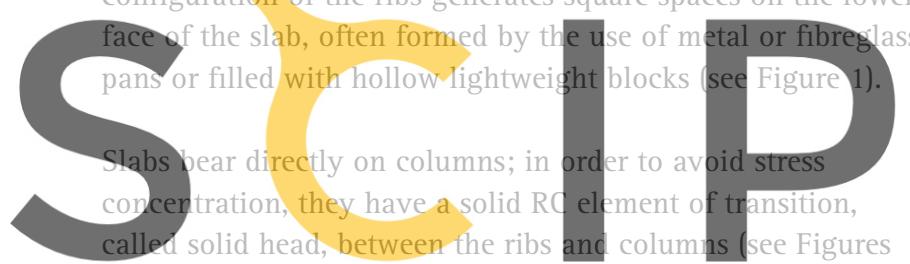

2(a) and 2(b)). Solid heads are reinforced in two directions, but

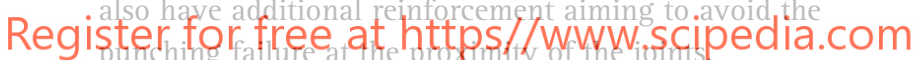

The WSFB under study has three stories: the first one is $4.5 \mathrm{~m}$

high, whereas the other two are $3.0 \mathrm{~m}$ high; this is a typical configuration for a building whose ground floor is intended for commercial use. Slab thickness is $30 \mathrm{~cm}$. A typical plan of this building is shown in Figure 3. Reinforcement details of this building are provided in the Appendix.

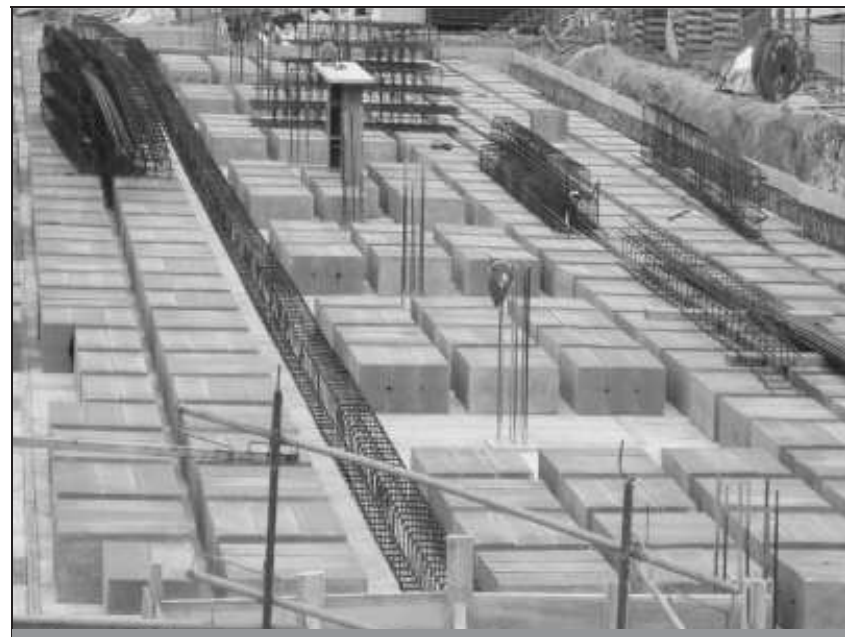

Figure I. View of a waffled-slab floor in construction process

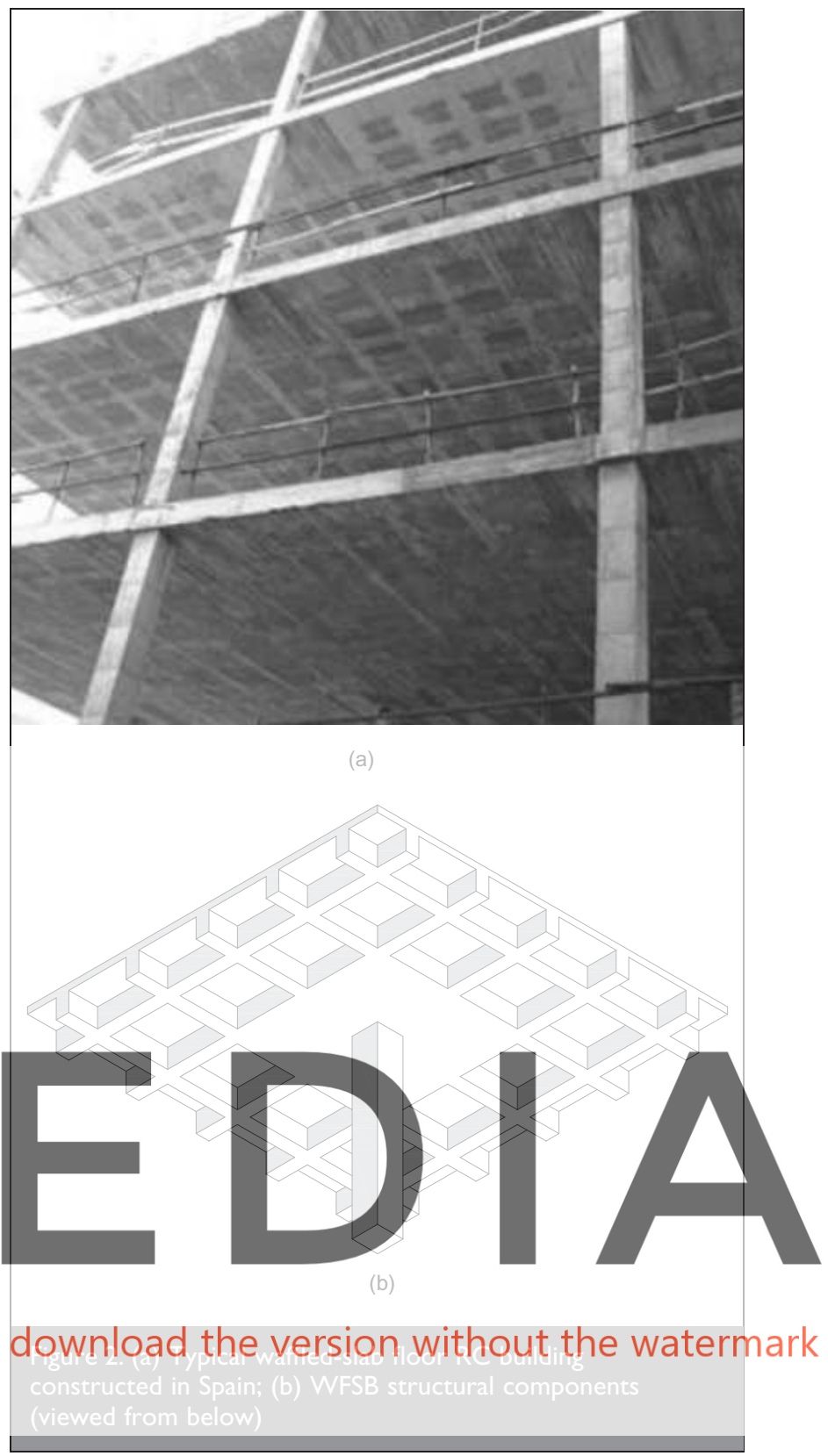

\subsection{RC moment-resisting frame buildings}

Two RC buildings were designed with the objective of studying the MRFB response: one according to the EHE and NCSE-02 Spanish codes; the second one according to ACI-318 and IBC2003 codes. Buildings have one-way ribbed slabs and seismic design criteria are added to increase the cross-section size of the columns, thereby yielding a structure with strong columns and weak beams. Further information about the geometry and reinforcement details of buildings can be seen in the Appendix. The characteristics of the materials of the three buildings are

(a) compressive concrete cylinder strength: $25 \mathrm{~N} / \mathrm{mm}^{2}$ (EHE) and $28 \mathrm{~N} / \mathrm{mm}^{2}$ (ACI-318)

(b) axial and shear yield strength of steel: $500 \mathrm{~N} / \mathrm{mm}^{2}$ (EHE) and $525 \mathrm{~N} / \mathrm{mm}^{2}$ (ACI-318).

\subsection{Seismic design of the buildings}

Seismic design of the buildings was performed using the inelastic spectrum prescribed by the NCSE-02 Spanish code for stiff soils and basic acceleration of $0 \cdot 23 \mathrm{~g}$ (see Figure 4). 


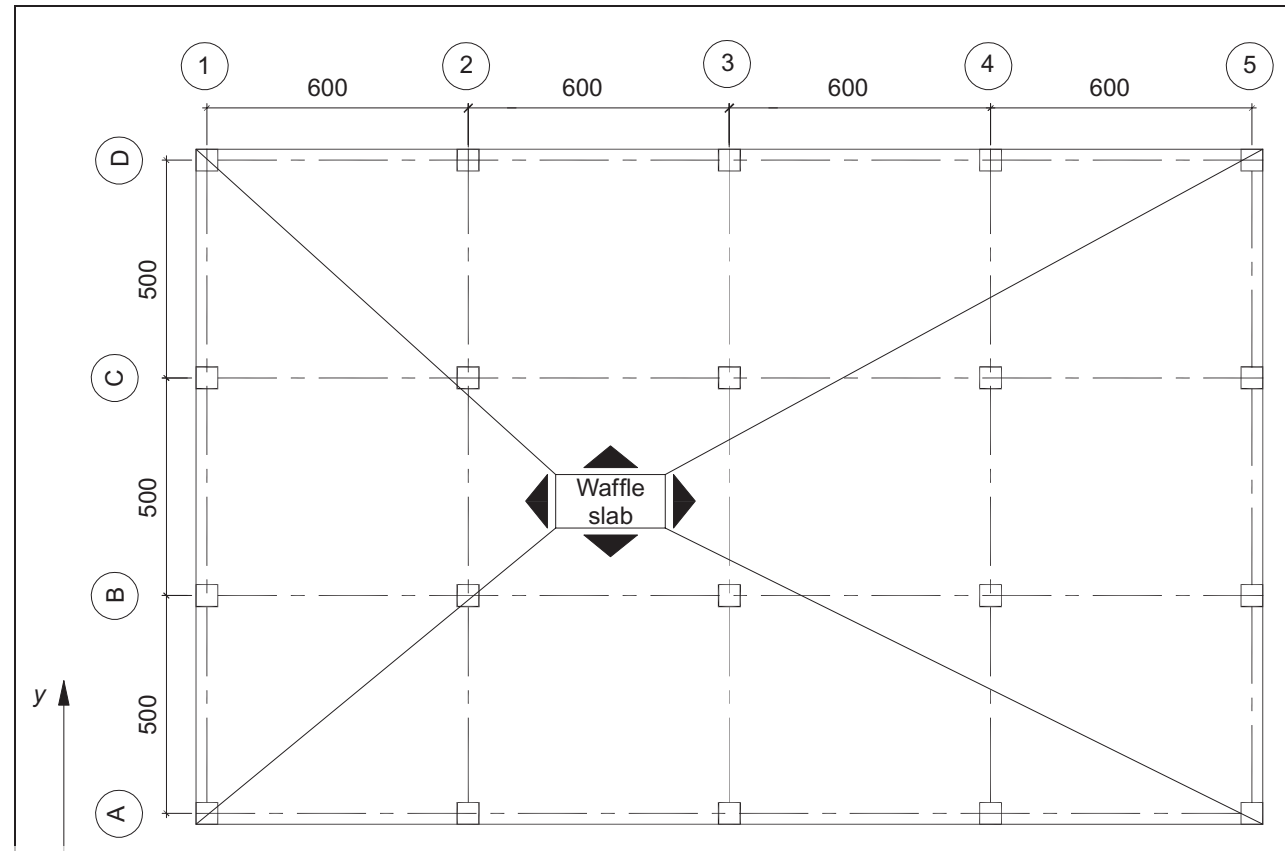

Seismic actions were calculated from the threedimensional (3D) modal analysis, in which three degrees of freedom for level were considered. Table 1 shows modal periods for the three buildings studied.

\section{PUSHOVER}

\section{ANALYSIS}

Buildings designed according to the linear elastic methods outlined in the seismic design codes have been studied using a push-over analysis. A single equivalent frame was modelled for each building. For the WSFB the equivalent frame is defined following the recommendations outlined in the ACI-318 code, with three main assumptions.

\section{(a) An equivalent frame is a two-dimensional (2D) frame defined by cutting}

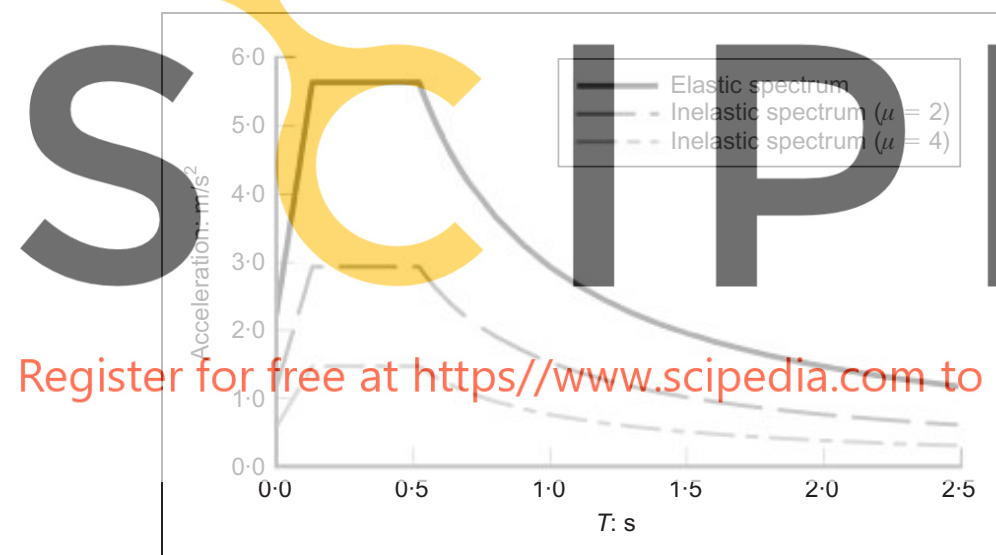

Figure 4. Elastic and inelastic spectrum used to perform dynamic analyses

\begin{tabular}{|lccc|}
\hline \multicolumn{3}{c|}{ Period: s } \\
\cline { 2 - 4 } Mode & WSFB & $\begin{array}{c}\text { MRFB } \\
\text { (EHE/NCSE-02) }\end{array}$ & $\begin{array}{c}\text { MRFB } \\
\text { (ACl-3 I8/IBC-2003) }\end{array}$ \\
\hline & & 0.45 & 0.41 \\
1 & 0.93 & 0.44 & 0.38 \\
2 & 0.91 & 0.39 & 0.37 \\
3 & 0.82 & 0.16 & 0.30 \\
4 & 0.27 & 0.16 & 0.29 \\
5 & 0.26 & 0.14 & 0.23 \\
6 & 0.23 & 0.09 & 0.22 \\
7 & 0.12 & 0.09 & 0.20 \\
8 & 0.11 & 0.08 & 0.17 \\
9 & 0.10 & & \\
\multicolumn{2}{|c|}{ Table I. Periods of the modes considered in buildings analyses } \\
\hline
\end{tabular}

3D building along lines midway between columns. For
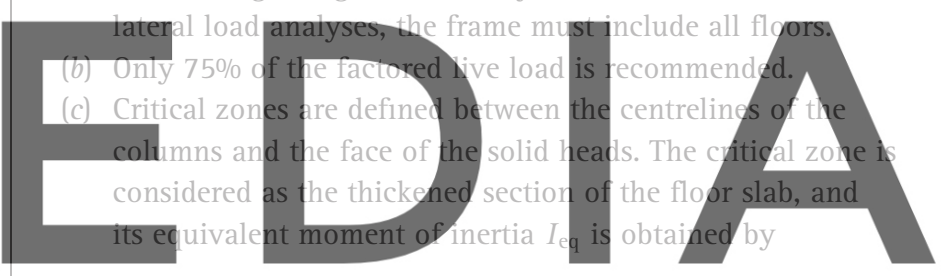

download the version without the watermark

where $I$ is the solid head moment of inertia, $c_{2}$ is the column width in the transverse direction and $l_{2}$ is that of the solid head; this procedure takes into account the shear failure in the critical zone. The equivalent slab moment of inertia can be calculated from its gross section, obtaining an equivalent depth of $19.45 \mathrm{~cm}$. Details of the equivalent frame are shown in Figure 5.

Non-linear static analysis with force control was performed using PLCd ${ }^{22}$ finite element code. ${ }^{23,24}$ PLCd is a finite element code that works with 2D and 3D solid geometries as well as with prismatic, reduced to one-dimensional (1D) members. This code provides a solution combining both numerical precision and reasonable computational costs. ${ }^{25,26}$ It can deal with kinematics and material non-linearities. It uses various 3D constitutive laws to predict the material behaviour (elastic, visco-elastic, damage, damage-plasticity, etc. ${ }^{27}$ ) with different yield surfaces to control their evolution (Von-Mises,

Mohr-Coulomb, improved Mohr-Coulomb, Drucker-Prager, etc. ${ }^{28}$ ). Newmark's method ${ }^{29}$ is used to perform the dynamic analysis. A more detailed description of the code can be found in Mata et al. ${ }^{25,26}$ The main numerical features included in the code to deal with composite materials are 


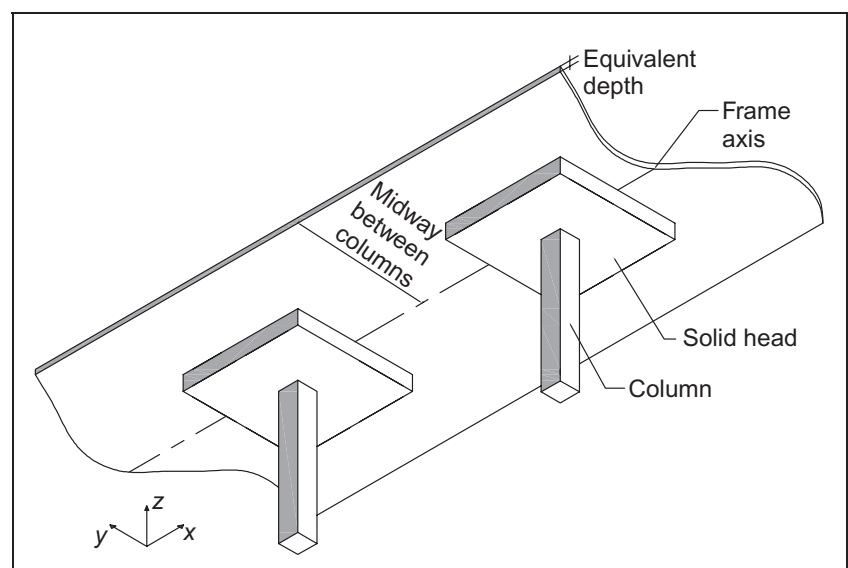

Figure 5. Details of equivalent frame used in the analysis of the WSFB

(a) classical and serial/parallel mixing theory used to describe the behaviour of composite components ${ }^{30}$

(b) anisotrony mapned snace theory enables the code to consider materials with a high level of anisotropy, without the associated numerical problems ${ }^{24,31}$

(c) Fibre-matrix debonding which reduces the composite strength due to the failure of the reinforced-matrix interface. $^{32}$

Experimental evidence shows that inelasticity in beam

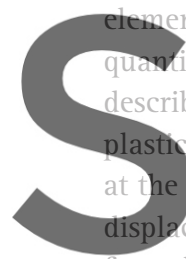
s can be formulated in term ties $^{33}$ and, therefore, the bea cribed by means of concentrated

the ends of the beam by means of a cement or moment-curvatur

ormulation used in this computer program, however, the procedure consists of obtaining the constitutive relationship at Registes-sfor free etthttestifyvarwsscipediandem to points corresponding to fibres directed along the beam's axis. ${ }^{35}$
So, the general non-linear constitutive behaviour is included in the geometrically exact non-linear kinematics formulation for beams proposed by Simo, ${ }^{25}$ considering an intermediate curved reference configuration between the straight reference beam and the current configuration. The displacement-based method is used for solving the resulting non-linear problem. Plane cross-sections remain plane after the deformation of the structure; therefore, no cross-sectional warping is considered, avoiding including additional warping variables in the formulation or iterative procedures to obtain corrected crosssectional strain fields. An appropriated cross-sectional analysis is applied for obtaining the cross-sectional forces and moments ${ }^{25}$ and the consistent tangential tensors in the linearised problem. Thermodynamically consistent constitutive laws are used in describing the material behaviour for these beam elements, which allows obtaining a more rational estimation of the energy dissipated by the structures. The simple mixing rule for composition of the materials is also considered in modelling materials for these elements, which are composed by several simple components. Special attention is paid to obtain the structural damage index capable of describing the load-carrying capacity of the structure.

\section{According to the mixing theory, in a structural element coexist $N$ different components, all of them subject to the same strain; therefore, strain compatibility is forced among the material components. Free energy density and dissipation of the composite are obtained as the weighted sum of the free energy}
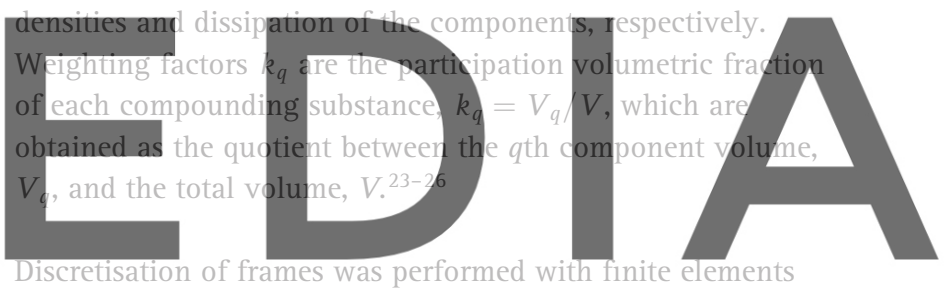

whose lengths vary depending on the column and beam zones

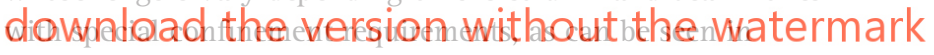

Figure 6. These confinement zones were designed according to

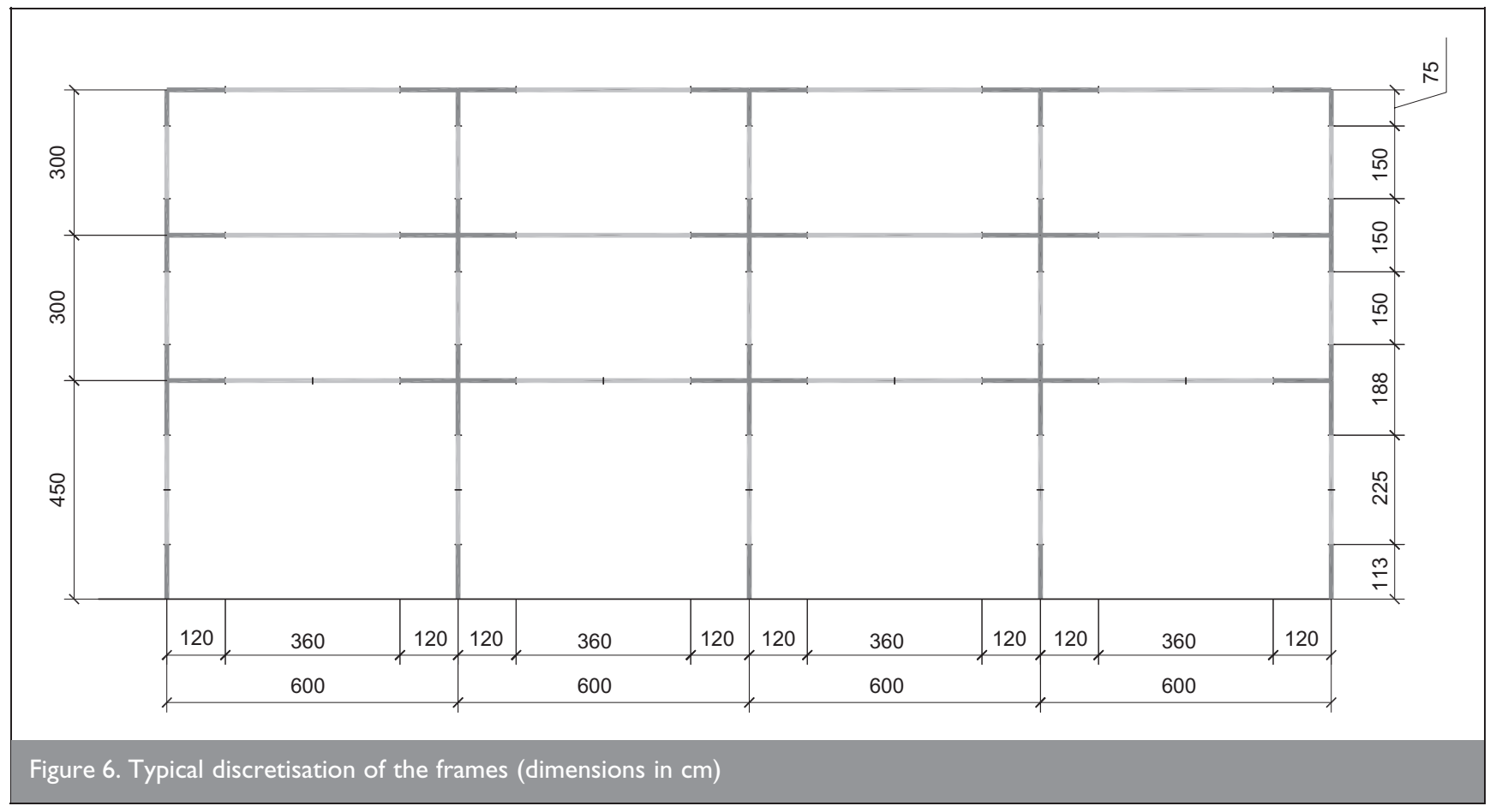


the general dimensions of the structural elements, the diameters of the longitudinal steel, the clear of spans and the storey heights. Frame elements are discretised into equal thickness layers with different composite materials, characterised by their longitudinal and transversal reinforcement ratio (see Figure 7). Transversal reinforcement benefits are included by means of the procedure proposed by Mander et al. ${ }^{36}$

The pushover analysis has been performed by applying a set of lateral forces corresponding to the seismic actions in the first vibration mode shape. Lateral forces are gradually increased starting from zero, passing through the value inducing transition from elastic to plastic behaviours and, finally reaching the value which corresponds to the ultimate drift (i.e. the point at which the structure can no longer support any additional load and collapses). Before the structure is subjected to the lateral loads simulating the seismic action, it is furst loaded with the gravity loads.

The non-linear static response obtained by way of finite element techniques is used to generate the idealised elastoplastic behaviour shown in Figure 8, which has a secant segment from its origin to a point $\left(\Delta_{y}, V_{y}\right), V_{y}$ being the $75 \%$ of maximum base shear. ${ }^{19}$ The second segment, representing the branch of plastic behaviour, is obtained by finding the intersection of the aforementioned segment with the horizontal corresponding to the maximum base shear. The use of the area

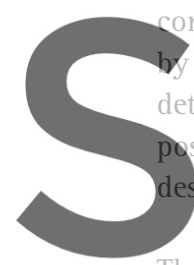
mpensation procedure guarar the ideal and the modelled etermine $\Delta_{\mathrm{y}}$ and $\Delta_{\mathrm{u}}$ (see Figure ssible to obtain the ductility
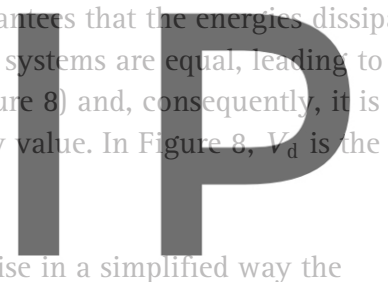

The variables which characterise in a simplified way the
quality of the building seismic behaviour are the structural Registerufoiryfree atedhatps//www.scipedia.com to
2

$$
\mu=\frac{\Delta_{\mathrm{u}}}{\Delta_{\mathrm{y}}}
$$

where $\Delta_{\mathrm{u}}$ is the ultimate drift obtained from the idealised capacity curve, and the overstrength $R_{\mathrm{R}}$ of the building, defined as

\begin{tabular}{|l|l|}
\hline 3 & $R_{\mathrm{R}}=\frac{V_{\mathrm{y}}}{V_{\mathrm{d}}}$ \\
\hline
\end{tabular}

where $V_{\mathrm{d}}$ is the design base shear and $V_{\mathrm{y}}$ is the yielding base shear (see Figure 8). The design base shear has been calculated using the procedure prescribed in most of the main seismic codes, applying the criteria of the square root of the sum of squares (SRSS) of the values of the forces obtained from modal analysis. Next, the design base shear is normalised respecting the total seismic weight of the structure. Overstrength $R_{\mathrm{R}}$ is similar to a safety factor applied in the design.

\section{WSFB NON-LINEAR RESPONSE}

The WSFB is designed according to the NCSE-02 and EHE Spanish codes for a structural ductility equal to two. Its capacity curve is calculated using a mechanical model similar to the equivalent frame defined in the ACI-318 code and it is shown in Figure 9(a). Analysis is performed by means of the finite element method and using damage and plasticity

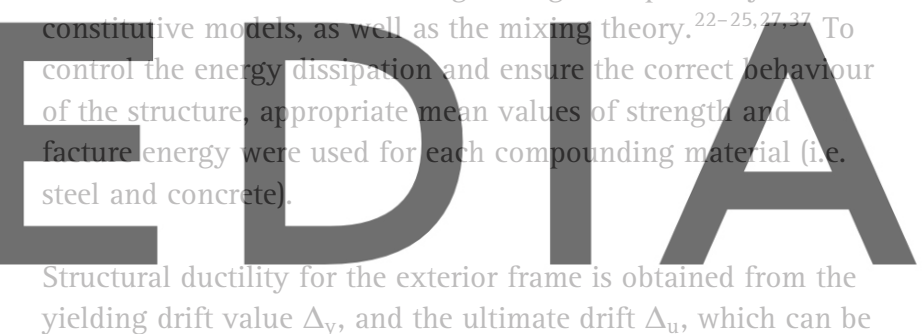

yielding drift value $\Delta_{\mathrm{y}}$, and the ultimate drift $\Delta_{\mathrm{u}}$, which can be downloadidaleversioncwitbout tha(e) watermark

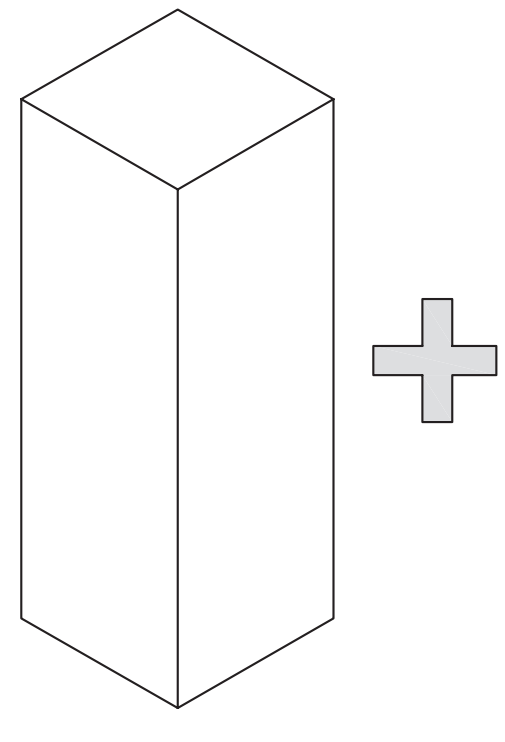

Concrete

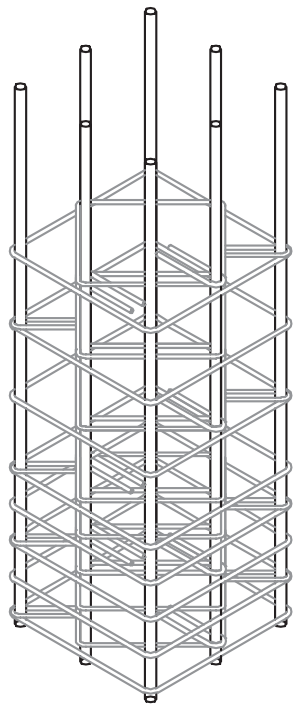

Steel

reinforcement

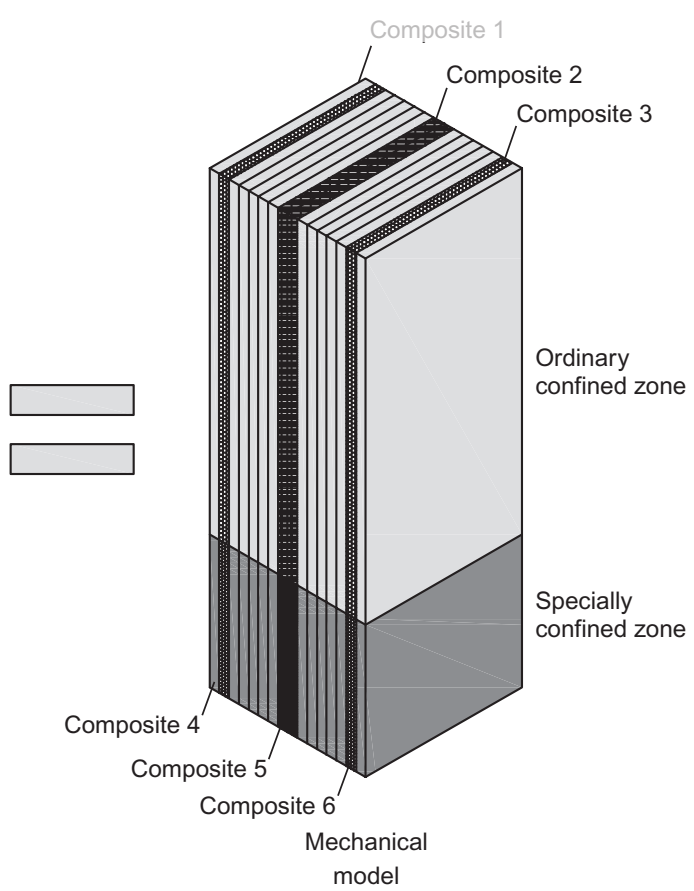




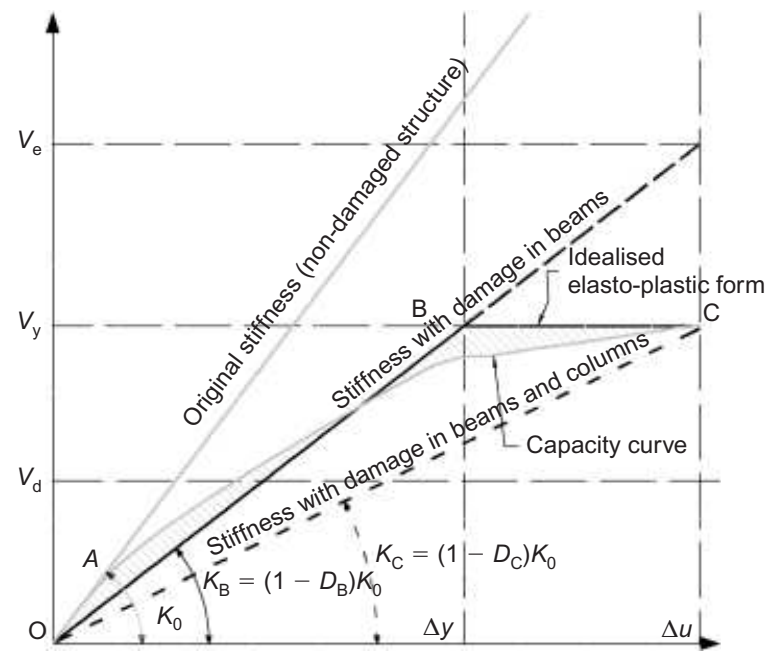

Drift: $\Delta$

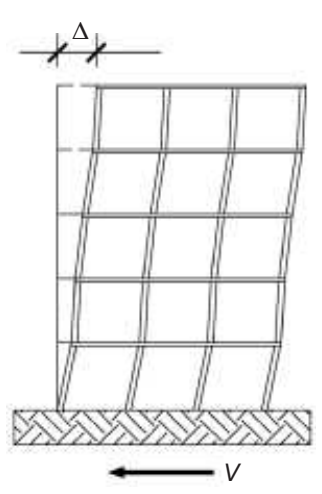

Figure 8. Scheme for determining the damage index of a structural element ductility values in the NCSE02 earthquake-resistant code should be revised.

Nevertheless, it is necessary to point that WSFB exhibit high overstrength level.

Figure 9(b) shows the evolution of the damage index for the studied waffledslab floor building, quantifying stiffness loss in the structural elements resisting loads or the loads leading to failure. This index is calculated using the finite element program PLCd with a constitutive damage and plasticity model that enables correlation of damage with lateral displacements ${ }^{30,38,39}$

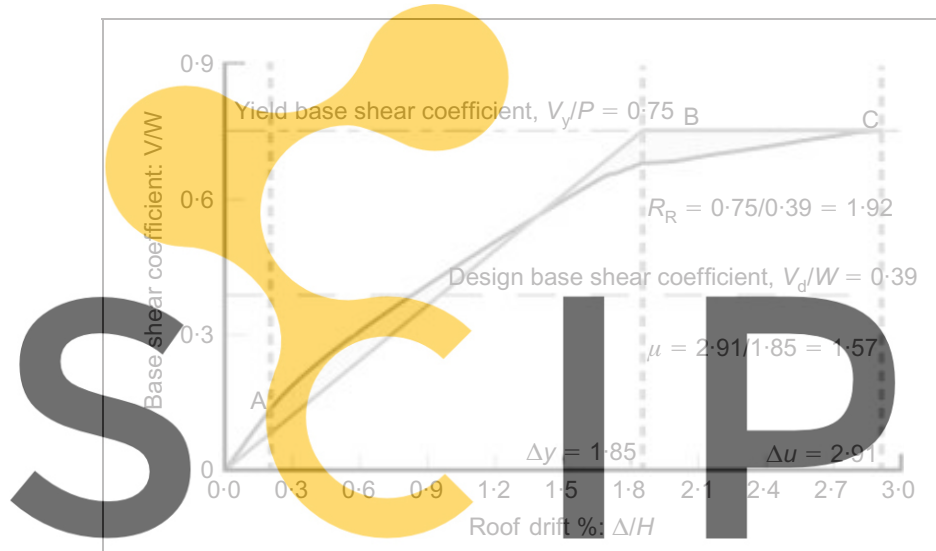

(a)

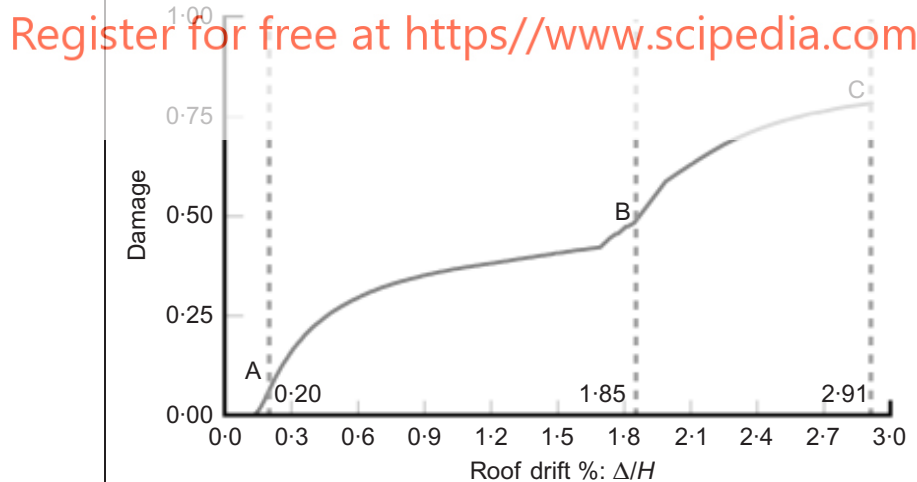

(b)

Figure 9. (a) Idealised bilinear capacity curve; (b) evolution of the global damage index of the WSFB exterior frame

$$
\mu=\frac{\Delta_{\mathrm{u}}}{\Delta_{\mathrm{y}}}=\frac{2 \cdot 91}{1.85}=1.57
$$

The value obtained is very low, even when compared with design value $\mu=2$ foreseen in the NCSE-02 Spanish code for this structural type. The overstrength is: $R_{\mathrm{R}}=\frac{V_{\mathrm{y}}}{V_{\mathrm{d}}}=1.92$. Ductility values calculated for this structural class are similar to those obtained for flat slab buildings ${ }^{12}$ and suggest that the

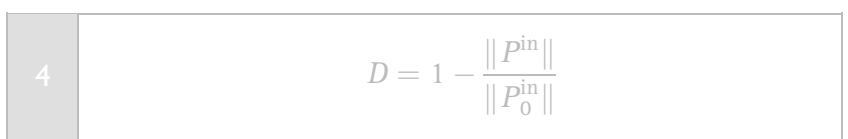

where $\left\|P^{\text {in }}\right\|$ and $\left\|P_{0}^{\text {in }}\right\|$ are the norm of current and elastic values of the internal forces vectors, respectively. Initially, the

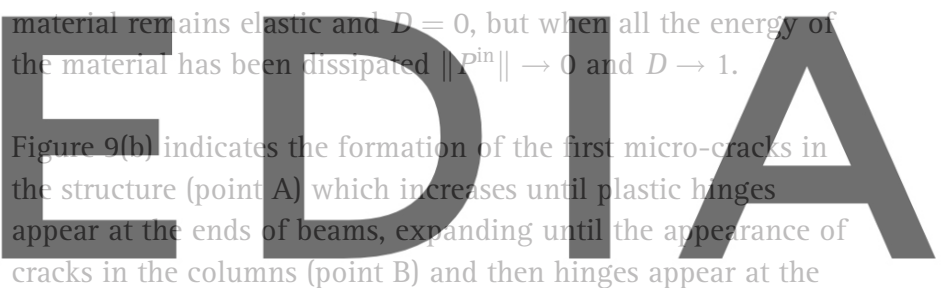
cracks in the columns (point B) and then hinges appear at the ends of the columns. Finally, the ultimate drift threshold is down(bad)thes version witbouidatine dwatermark correlate the capacity curve of Figure 9(a) with the damage curve of Figure 9(b). In the case of WSFB, it can be seen how the global damage index of the structure corresponding to the ultimate drift is of $77 \cdot 5 \%$.

The WSFB low ductility response can be attributed to the formation of plastic hinges in the transition points between the solid head and the slab ribs at the first floor. Slab elements are subjected to bending induced by gravity loads, as well as to the demands of seismic forces; hence, the zones requiring special reinforcement are those closest to the slab-column node and to the middle of the span, where the greatest bending moments frequently appear. Efficient confinement in the central slab zone is, however, technically complicated. This suggests the existence, during earthquakes, of a possible mechanism of structural failure, at the transition zone between the solid slab and the ribs, and consequently, a low level of structure ductility (see Figure 10).

\section{MRFB NON-LINEAR RESPONSE}

The capacity curve of the MRFB designed according to the EHE and NCSE-02 Spanish codes is shown in Figure 11(a). The curve clearly illustrates how this structural type is capable of sustaining a stable ductile response, which is reflected in the high value of the ultimate drift. Based on the idealised bilinear 

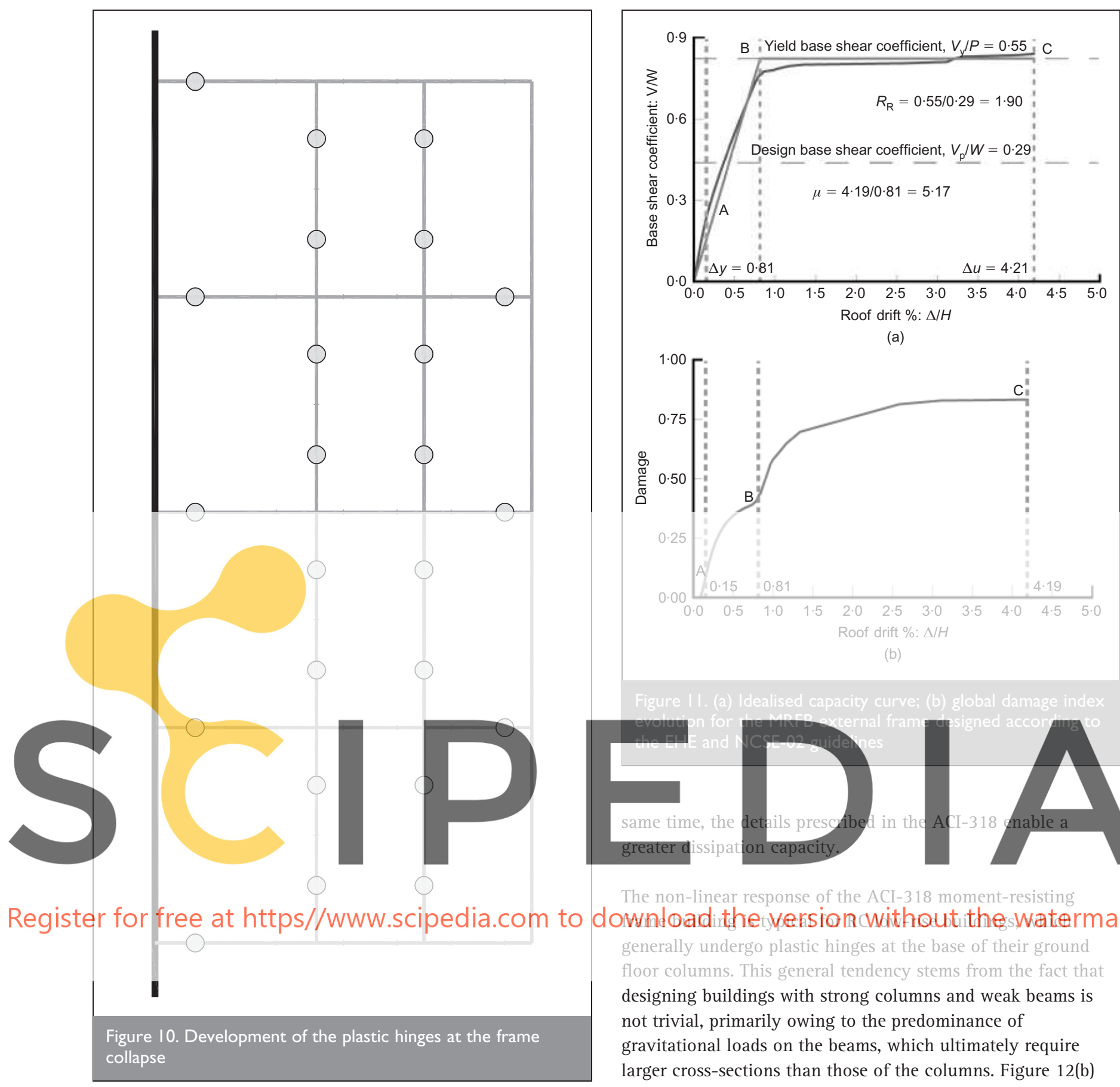

(a)
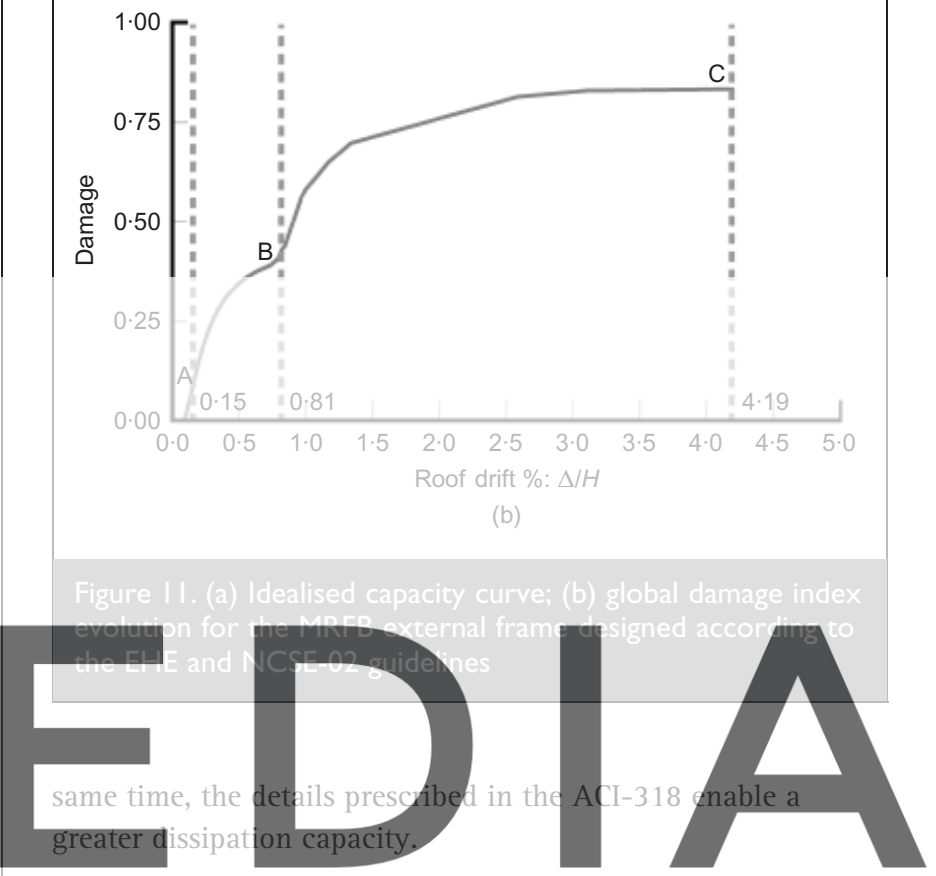

The non-linear response of the ACI-318 moment-resisting d owind oadinthe yersion waithoutithes, watermark generally undergo plastic hinges at the base of their ground floor columns. This general tendency stems from the fact that designing buildings with strong columns and weak beams is not trivial, primarily owing to the predominance of gravitational loads on the beams, which ultimately require larger cross-sections than those of the columns. Figure 12(b) shows that in this case the structure maximum global damage index is $93 \%$.

curve of Figure 11(a), a ductility of 5.17 is obtained; this is a higher value than the one considered in the design, which is 4 . This means that MRFB has a ductile response to seismic forces, as well as an adequate overstrength. Figure 11(b) shows the evolution of the global damage index for this type of building, with a maximum damage index of $82 \%$ corresponding to the ultimate roof drift.

Figures 10(a) and 10(b) show the capacity curve and the evolution of the damage, respectively, for the external frame of the building designed according to the ACI-318. The main difference between this building and the former is, on the one hand, that the Spanish NCSE-02 earthquake-resistant code limits to four the ductility for this class of buildings to four and, on the other hand, that this code requires less transversal and longitudinal reinforcement than the ACI-318 (2005). At the

The above mentioned procedure has been validated by means of non-linear dynamic analyses. The dynamic procedure consists of applying sinusoidal ground acceleration with a peak value scaled with respect to gravity acceleration and increased until yielding is reached. Results obtained shows that the static non-linear procedure allows for accurate calculation of displacements, and that the non-linear dynamic response of the WSFB under study shows a clear pinching behaviour, see Figure 13(b).

\section{FRAGILITY CURVES AND DAMAGE PROBABILITY MATRICES}

In order to evaluate the non-linear behaviour of the buildings, the performance points were calculated by applying the N2 procedure. ${ }^{40}$ The performance points are defined as the intersection of the capacity spectrum (obtained from the 


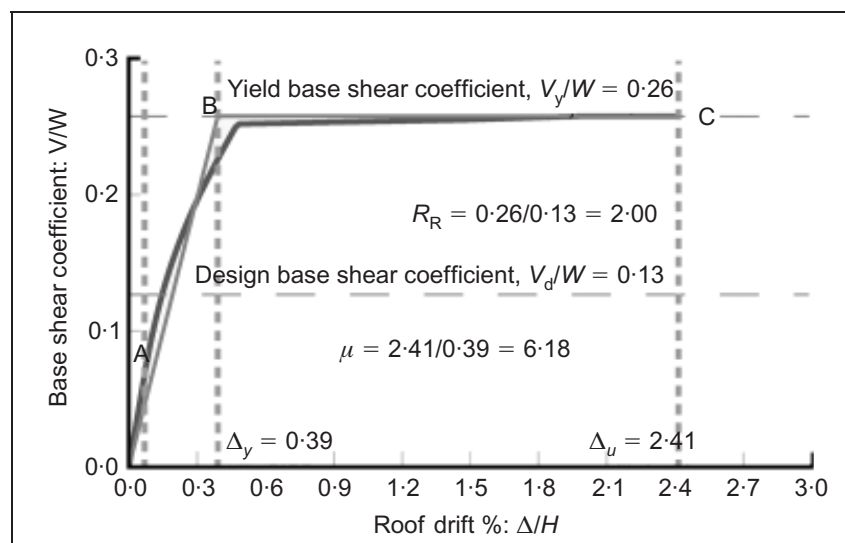

(a)

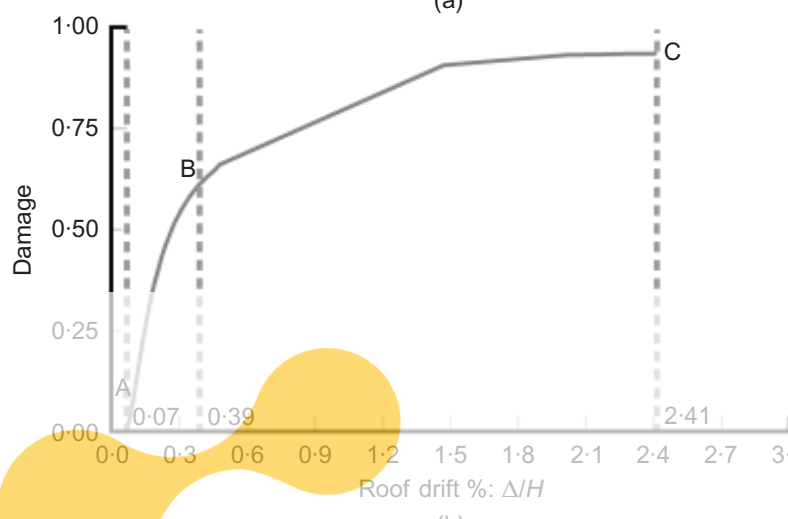

(b)

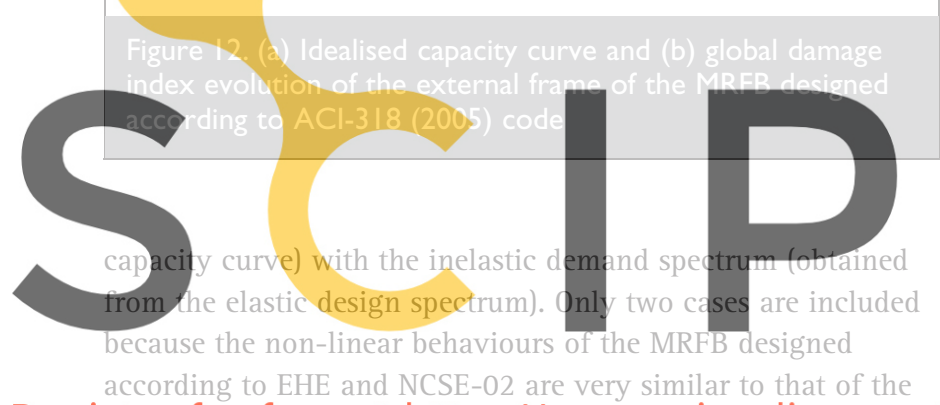

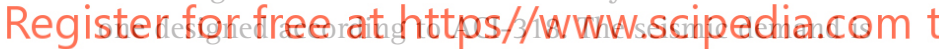

obtained from the elastic spectrum prescribed by NCSE (see

Figure 4). Roof drifts are transformed into spectral.

displacements through the equation

\begin{tabular}{|l|l|}
\hline 5 & $S_{\mathrm{d}}=\frac{\delta_{\mathrm{c}}}{\mathrm{MPF}}$ \\
\hline
\end{tabular}

where $S_{\mathrm{d}}$ is the spectral displacement, $\delta_{\mathrm{c}}$ is the roof drift and MPF is the modal participation factor corresponding to first mode. Values of the spectral displacements obtained for the performance point are shown in Table 2 .

Figures 14 and 15 show the capacity curves of each building together with the stiffness corresponding to initial undamaged state, to performance point and to ultimate drift. It can be observed how close performance and ultimate drift points are in the case of WSFBs.

Damage thresholds are determined using the of Vision 2000 procedure which expresses the thresholds in function of interstorey drifts. Damage-states thresholds are determined from both interstorey drift curve and capacity curve. Slight damage state is defined as the roof drift corresponding to the first plastic hinge. The moderate damage state corresponds to the roof drift for which an interstorey drift of $1 \%$ is reached at

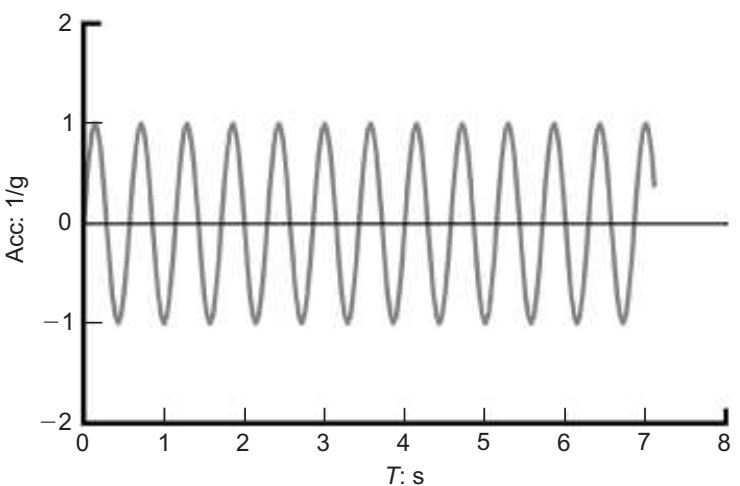

(a)

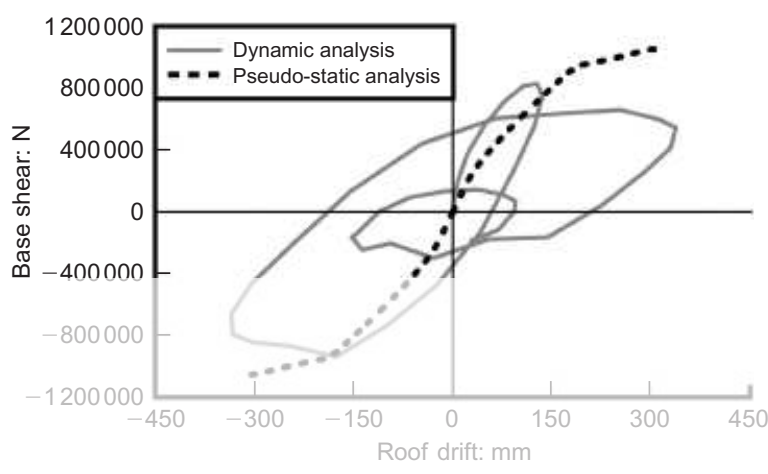

(b)

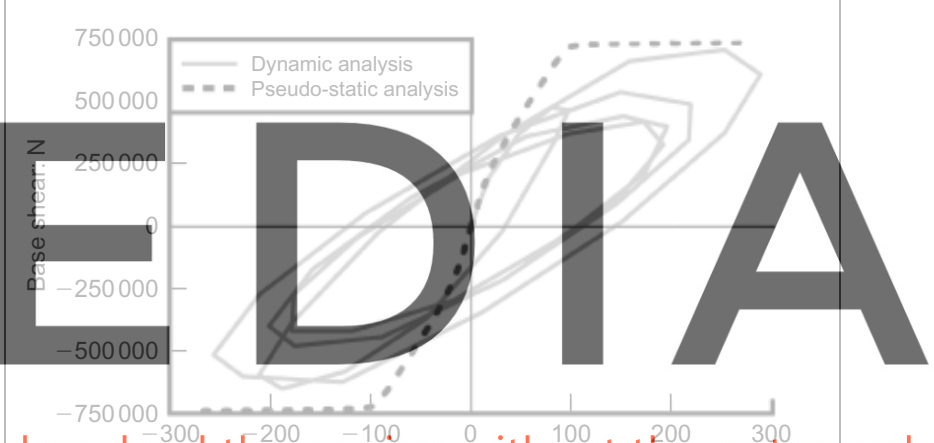

download the versiRs dwithout the watermark

(c)

Figure 13. Dynamic response of the two buildings designed

according to the NCSE-02: (a) applied sinusoidal excitation;

(b) WSFB and (c) MRFB

\begin{tabular}{|lc|}
\hline Building & Roof drift of the performance point: $\mathrm{mm}$ \\
\hline $\begin{array}{l}\text { WSFB } \\
\text { MRFB }\end{array}$ & $222 \cdot 07$ \\
$120 \cdot 18$
\end{tabular}

each level. Severe damage state is identified by a roof drift which produces a $2 \cdot 5 \%$ of interstorey drift at each level. Finally, the total damage state (collapse) corresponds to the ultimate roof displacement obtained from the capacity curve. Values of the mean and standard deviation of the roof drift normalised with respect to the building height are shown in Table 3.

Fragility curves are obtained by considering a lognormal 


\begin{tabular}{|llllll|}
\hline & \multicolumn{2}{c}{ WSFB } & & \multicolumn{2}{c|}{ MRFB } \\
\cline { 2 - 3 } \cline { 5 - 6 } & & Mean & $\begin{array}{c}\text { Standard } \\
\text { Limit state }\end{array}$ & Mean & $\begin{array}{c}\text { Standard } \\
\text { deviation }\end{array}$ \\
\hline Slight damage & 0.22 & 0.03 & & 0.16 & 0.02 \\
Moderate damage & 0.67 & 0.04 & & 0.93 & 0.05 \\
Severe damage & 1.67 & 0.11 & & 2.06 & 0.10 \\
Collapse & 2.91 & 0.16 & & 4.19 & 0.14 \\
Table 3. Mean values and standard deviation of the normalised \\
roof drift for limit states
\end{tabular}

probability density function for the spectral displacements defining damage states

\begin{tabular}{|l|l|}
\hline 6 & $F\left(S_{\mathrm{d}}\right)=\frac{1}{\beta_{\mathrm{ds}} S_{\mathrm{d}} \sqrt{2 \pi}} \exp \left[-\frac{1}{2}\left(\frac{1}{\beta_{\mathrm{ds}}} \ln \frac{S_{\mathrm{d}}}{\bar{S}_{\mathrm{d}, \mathrm{ds}}}\right)^{2}\right]$ \\
\hline
\end{tabular}

where $\bar{S}_{\mathrm{d}, \mathrm{ds}}$ is the mean value of spectral displacement for which the building reaches the damage-state threshold $d_{\mathrm{s}}$ and $\beta_{\text {ds }}$ is the standard deviation of the natural logarithm of the spectral displacement for damage state $d_{\mathrm{s}}$. The conditional probability $P\left(S_{\mathrm{d}}\right)$ of reaching or exceeding a particular damage state $d_{\mathrm{s}}$, given the spectral displacement $S_{\mathrm{d}}$, is defined as

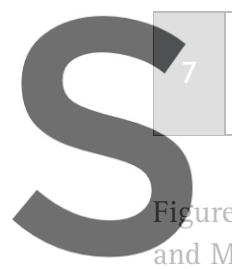
d MRFB, respectively.
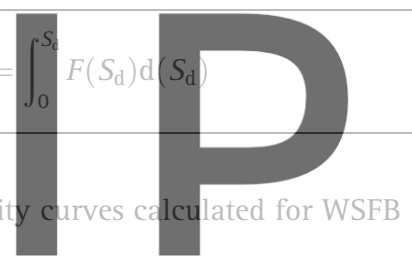

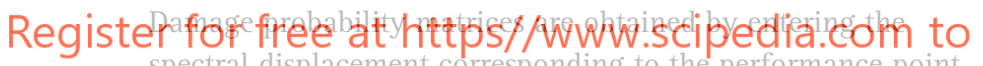
into the fragility curves. The values obtained represent the exceeding probabilities of a damage state and are given in Table 4 for the WSFB and MRFB considered in the analysis.

Table 4 shows that, for the demand being considered, there is a high probability that the limited ductility buildings exceed the severe damage state and the collapse state. Severe damage state exceeding probability is of $36 \cdot 2 \%$ for the WSFB. The collapse

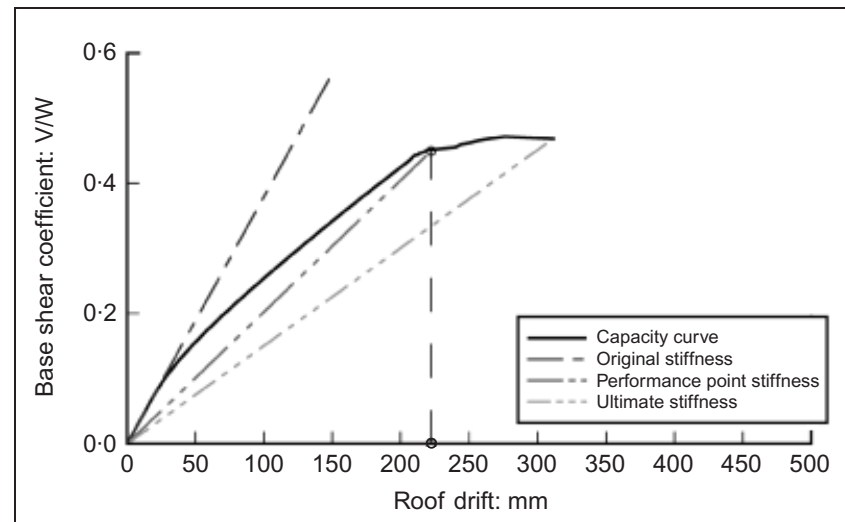

Figure 14. Roof drift corresponding to WSFB performance point

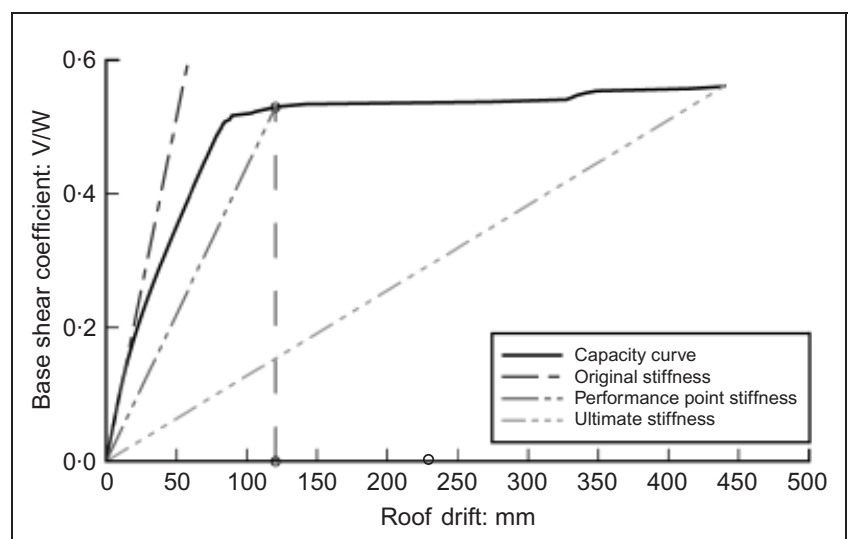

Figure 15. Roof drift corresponding to the performance point of the building with moment- resisting frames (NCSE-02 code)

\begin{tabular}{|c|c|c|}
\hline & WSFB & MRFB \\
\hline $\begin{array}{l}\text { No damage } \\
\text { Slight } \\
\text { Moderate } \\
\text { Severe } \\
\text { Collapse }\end{array}$ & $\begin{array}{r}0.2 \% \\
9 \cdot 4 \% \\
24 \cdot 6 \% \\
36 \cdot 2 \% \\
29 \cdot 6 \%\end{array}$ & $\begin{array}{r}0.4 \% \\
40 \cdot 3 \% \\
44.4 \% \\
13.9 \% \\
1.0 \%\end{array}$ \\
\hline \multicolumn{3}{|c|}{$\begin{array}{l}\text { Table 4. Damage probability matrices for the studied building } \\
\text { typologies }\end{array}$} \\
\hline
\end{tabular}

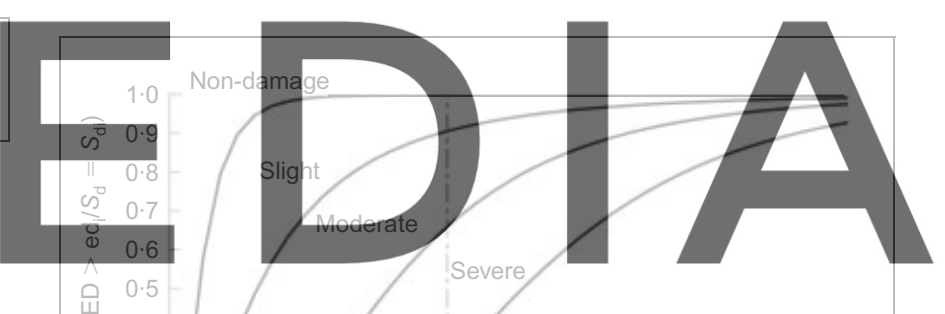

dovintoad the version witfiouse the watermark

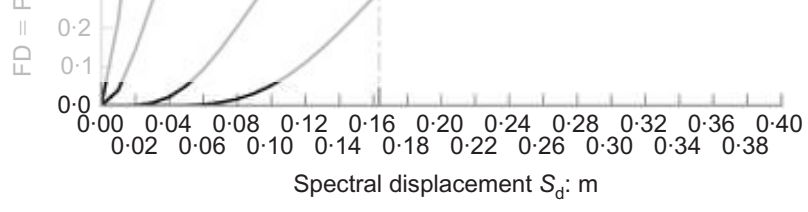

Figure 16. Fragility curves for WSFB

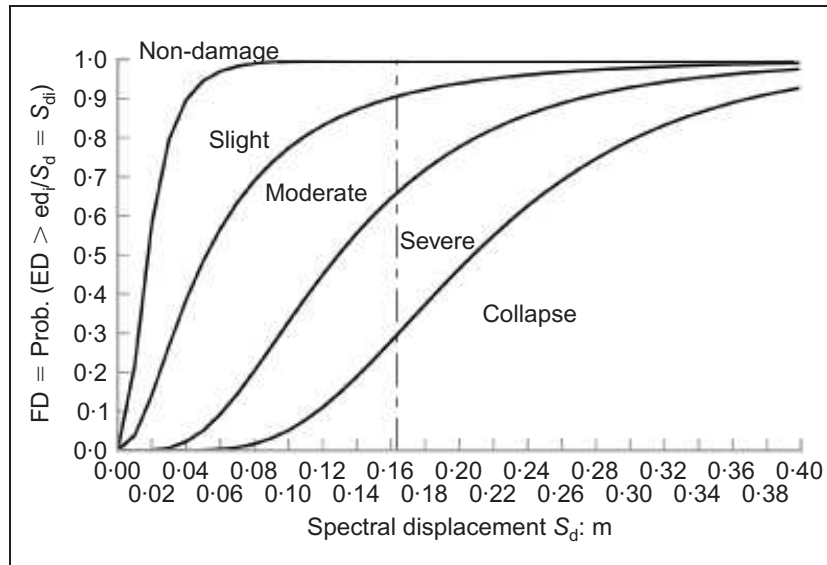

Figure 17. Fragility curves for MRFB designed according to the Spanish codes 
probabilities are $29 \cdot 6 \%$ for the WSFB and only about $1 \%$ for the MRFB.

\section{POSSIBILITIES OF IMPROVING THE SEISIMC RESPONSE OF WSFBS}

Figure 18 shows the capacity curves corresponding to all cases under study. Design base shears have also been plotted in this figure, in which it is evident that each of the three buildings has base shear coefficients greater than the design one, indicating that they satisfy this initial design objective. However, overstrength varies dramatically among the three structures. It is interesting to compare the MRFB capacity curves, which have similar structural typology but are designed with different codes and thus their reduction factors differ. Both exhibit ductility several times higher than that of the WSFB while providing satisfactory overstrength.

Results of the WSFB non-linear analysis raise this question; can their response be improved at design stage, in order to reach the ductility values prescribed in the NCSE-02 code maintaining the same structural typology? This section discusses this possibility based on the pushover analysis performed using the finite element method and comparing responses obtained with those corresponding to the MRFB. For the purpose of studying the influence of the steel type on the WSFB non-linear response, steels with different mechanical characteristics are considered. Buildings are calculated by

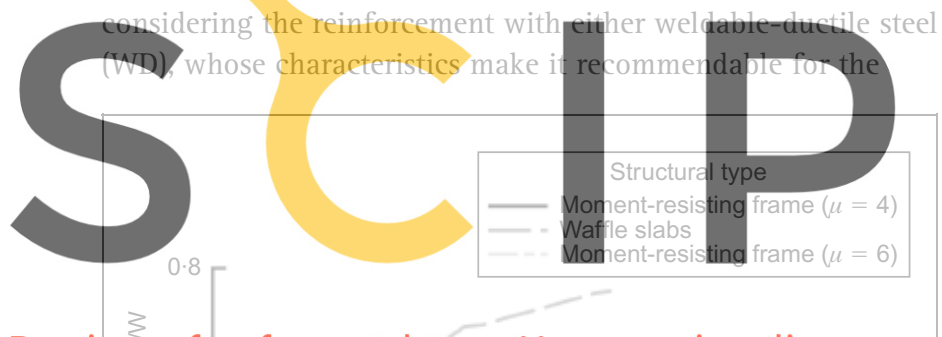

Register for free at https//www.scipedia.com

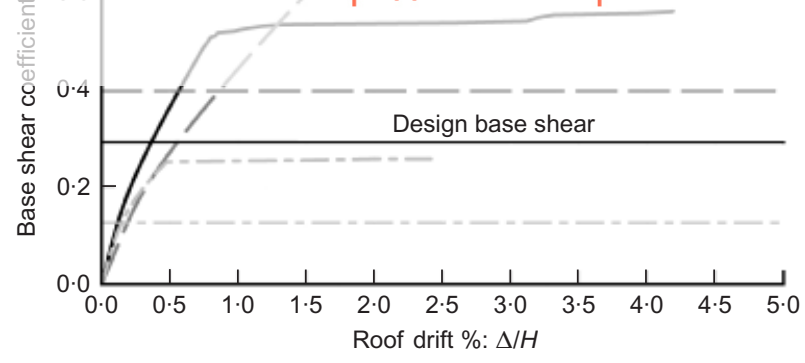

Figure 18. Comparison of the non-linear response of the three building types under study earthquake-resistant design of structures according to the EHE and Eurocode 8 specifications, or weldable steel (W) (see Table 5). For both cases, the yielding stresses B 400 and B 500 steel were considered (see Figure 19).

Results of the pushover analysis are shown in Figure 19, which reveals that frames reinforced with ductile steel have only a slightly more ductile response than do those reinforced with non-ductile steel. Hence, the building global response is influenced to a much greater extent by the general configuration and structural typology chosen than by the characteristics of the reinforcement steel.

Finally, Figure 20 shows the same results obtained for the MRFB reinforced with different types of steel. Observe that, in

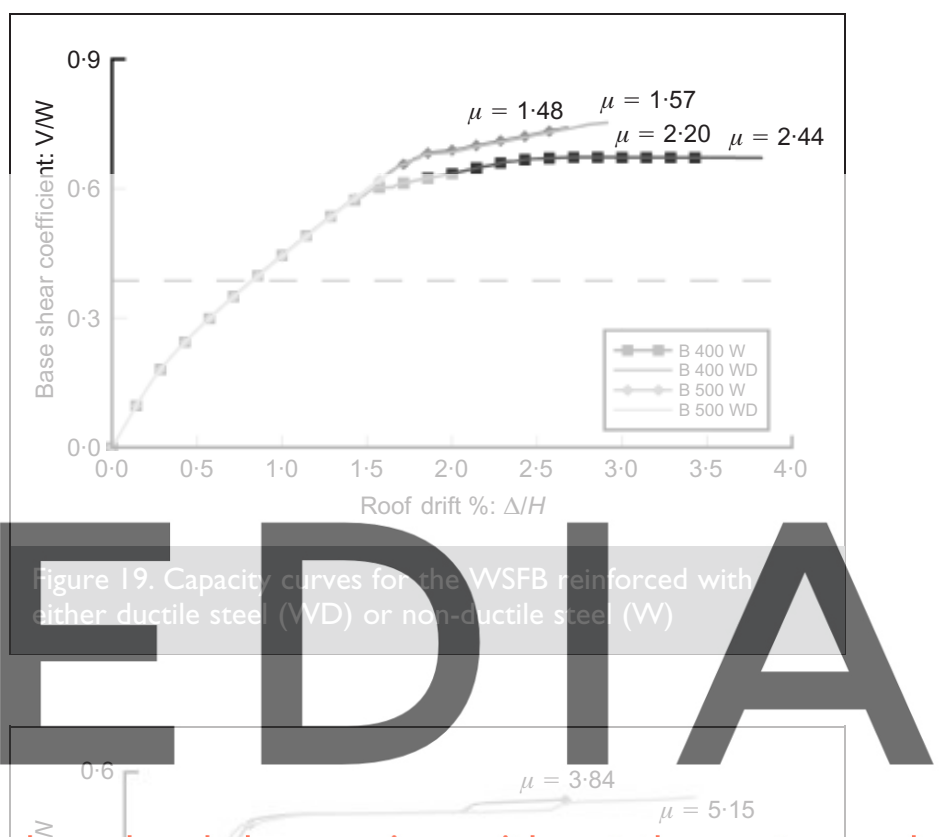

download the version without thes watermark

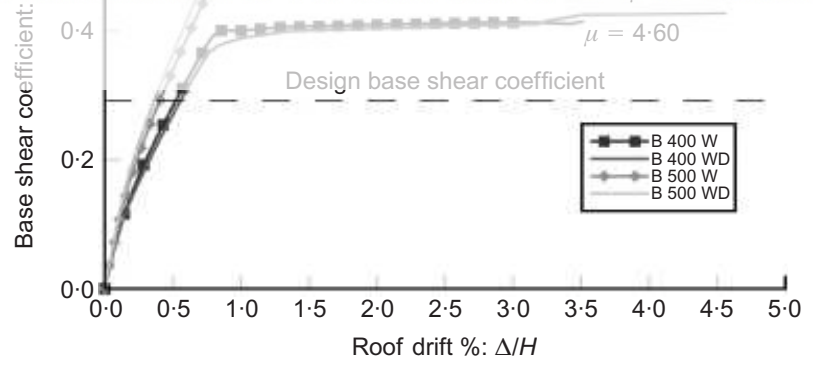

Figure 20. Capacity curve for the MRFB reinforced with steel having different mechanical characteristics

\begin{tabular}{|c|c|c|c|c|}
\hline \multirow[b]{2}{*}{ Steel type } & \multicolumn{2}{|c|}{ Eurocode 8} & \multicolumn{2}{|c|}{ EHE } \\
\hline & B & C & B 400 WD & B 500 WD \\
\hline Yield stress $f_{y}: N / m^{2}$ & $400-600$ & $400-600$ & 400 & 500 \\
\hline Ultimate stress $f_{s}: N / \mathrm{mm}^{2}$ & - & - & 480 & 575 \\
\hline Ratio $f_{s} / f_{y}$ & $\geqslant 1.08$ & $\geqslant 1.15$ and $\leqslant 1.35$ & $\geqslant 1.20$ and $\leqslant 1.35$ & $\geqslant 1.15$ and $\leqslant 1.35$ \\
\hline Maximum strain $\varepsilon_{\max }: \%$ & $\geqslant 5.0$ & $\geqslant 7.5$ & $\geqslant 9.0$ & $\geqslant 8.0$ \\
\hline Ultimate strain, $\varepsilon_{\mathrm{u}}: \%$ & - & - & $\geqslant 20.0$ & $\geqslant 16.0$ \\
\hline
\end{tabular}


this case, increasing the steel ductility leads to a major increase in structural ductility.

\section{CONCLUSIONS}

(a) The WSFB seismic behaviour has been studied using the pushover analysis with force control. In order to determine the structure ultimate drift threshold, global damage index must approximate to a value of $0 \cdot 8$. Yielding drifts of the structures are obtained using the idealised bilinear capacity curves proposed by Park.

(b) Among the cases studied only the MRFB exhibit sufficient ductility and overstrength to guarantee a stable behaviour, showing ductility values higher than those of the design.

(c) It has been proved in this paper that WSFB should be designed for lower ductility levels than those prescribed in the Spanish seismic code (NCSE-02) because the prescribed design values $(\mu=2)$ are greater than the obtained from numerical simulations ( $\mu=1 \cdot 57)$. Nevertheless, during earthquakes, WSFB show adequate overstrength.

(d) It can also be seen that the exceeding probabilities for the MRFB damage states are lower than those of WSFB. (e) Structural response of the WSFB cannot be improved using better mechanical characteristics of materials or a better confinement of their members.

(f) The only possibility of improving the WSFB behaviour is to add depth beams to in order to increase their lateral stiffness.

\section{ACKNOWLEDGEMENTS}

This research was partially supported by Fundación Gran Mariscal de Ayacucho (FUNDAYACUCHO), Universidad Centroccidental Lisandro Alvarado (UCLA); by the European Commission, FP6 project Risk Mitigation for Earthquakes and Landslides (LESSLOSS) (GOCE-CT-2003-505448); by the Spanish Government: Ministerio de Fomento (C21-06) and Ministerio de Ciencia y Tecnología, Project Delamination of reinforced matrix composites (DECOMAR) (MAT-2003-09768C03-02); Ministerio de Educación y Ciencia, Project HABITAT 2030 (PSS-380000-2005-14); Project Seguridad y durabilidad de estructuras de construcción (SEDUREC) (CSD2006-00060). All this support is gratefully acknowledged.

\section{APPENDIX}

Reinforcement details of the three studied buildings

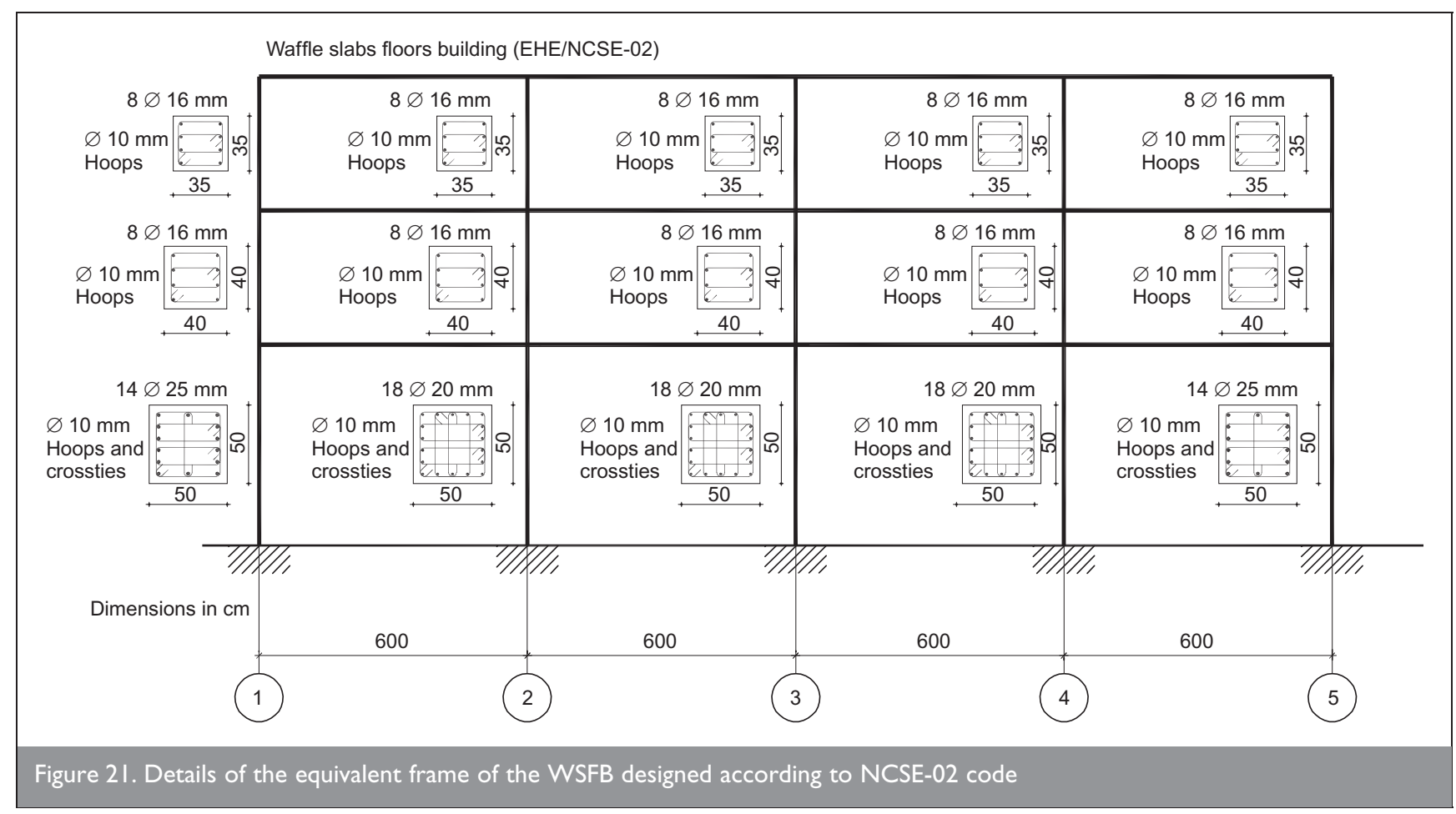




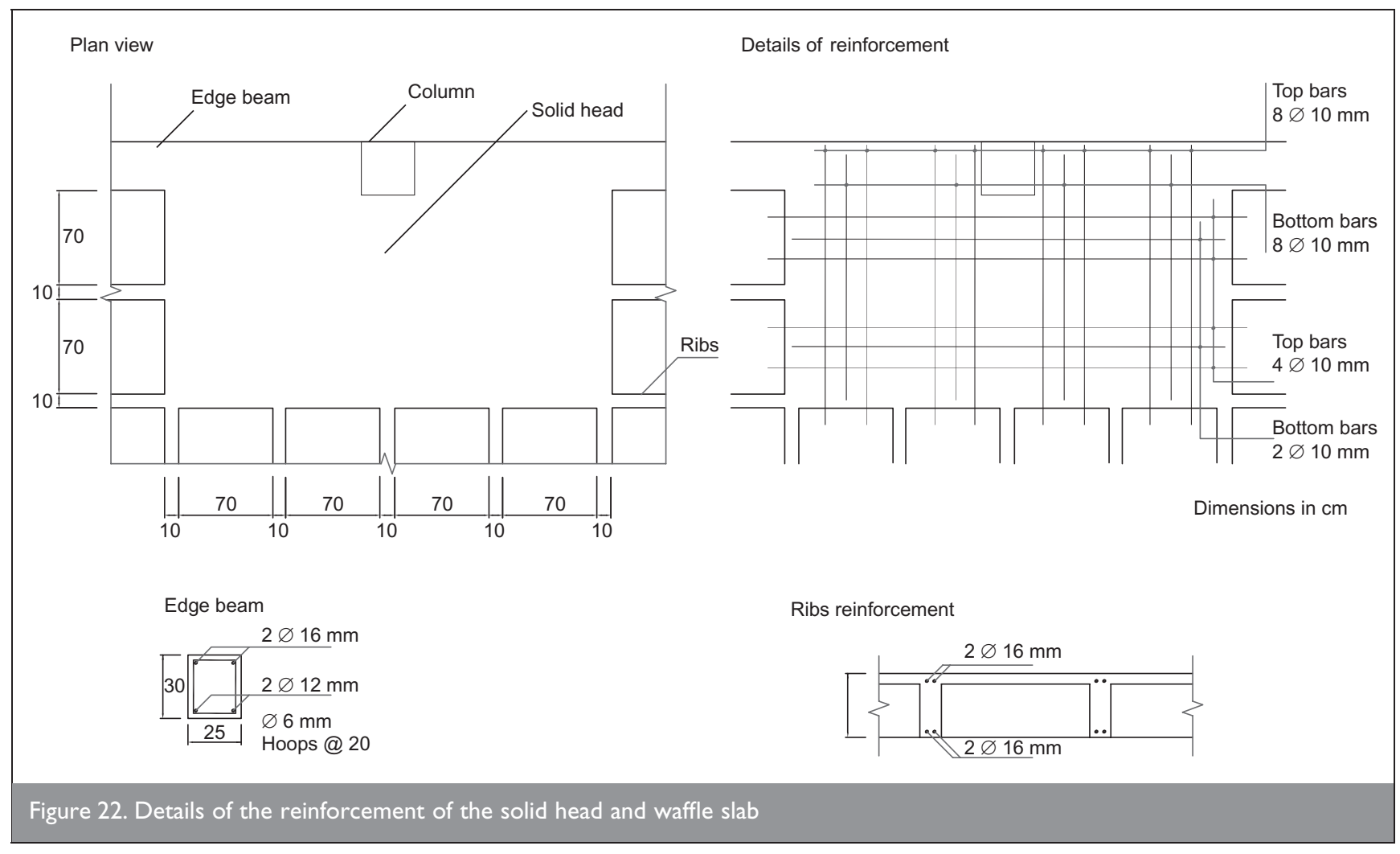

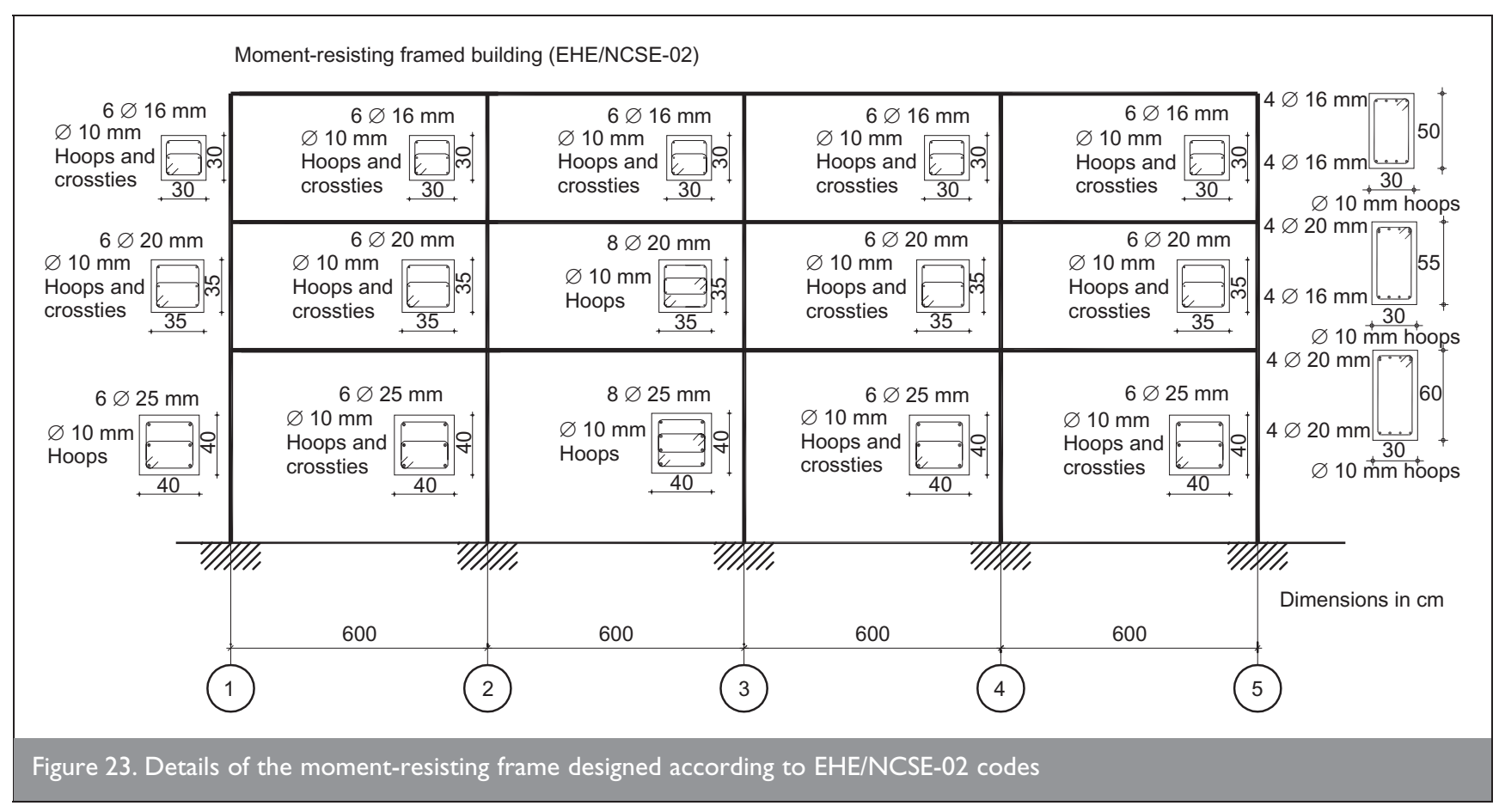




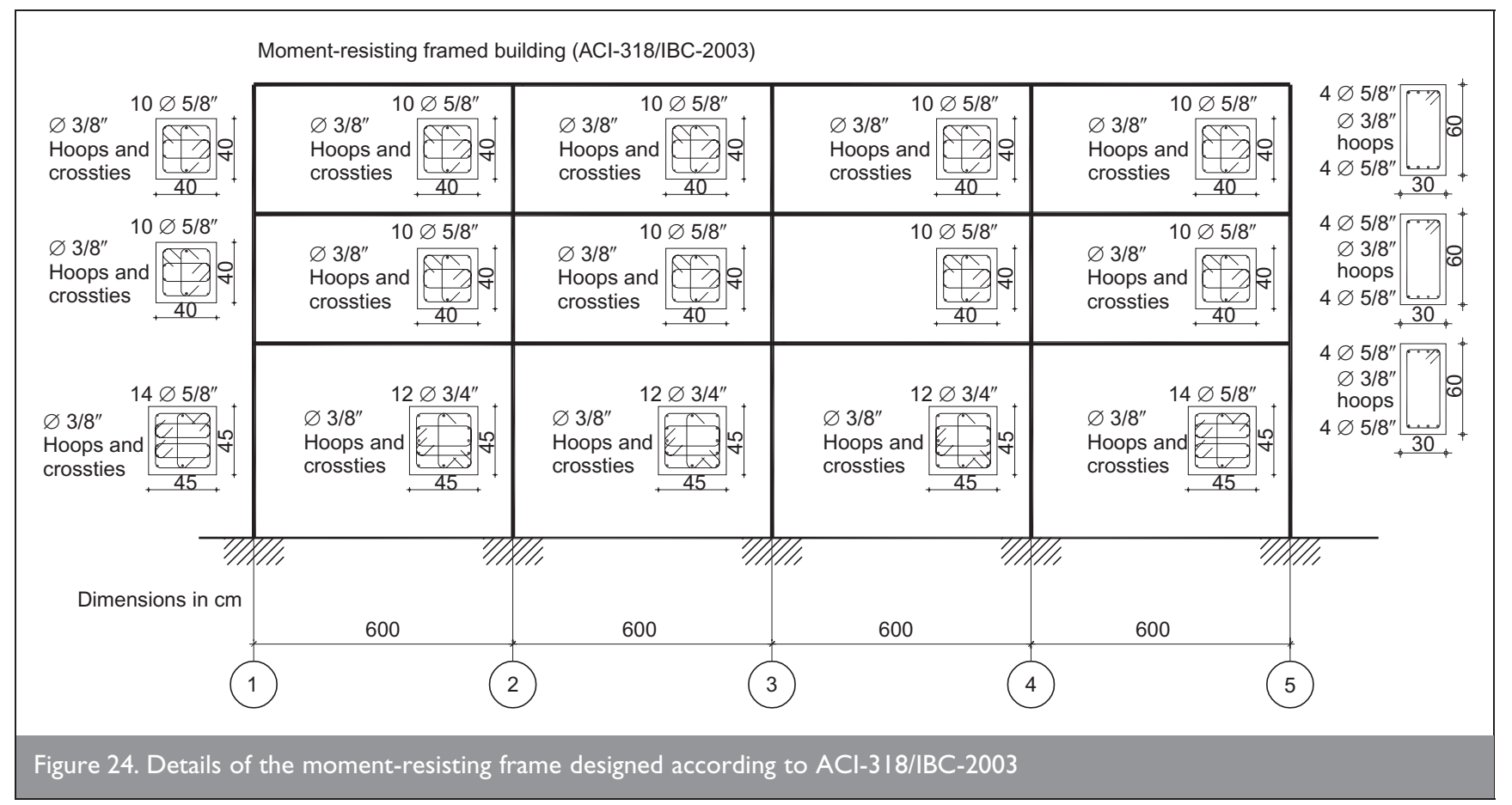

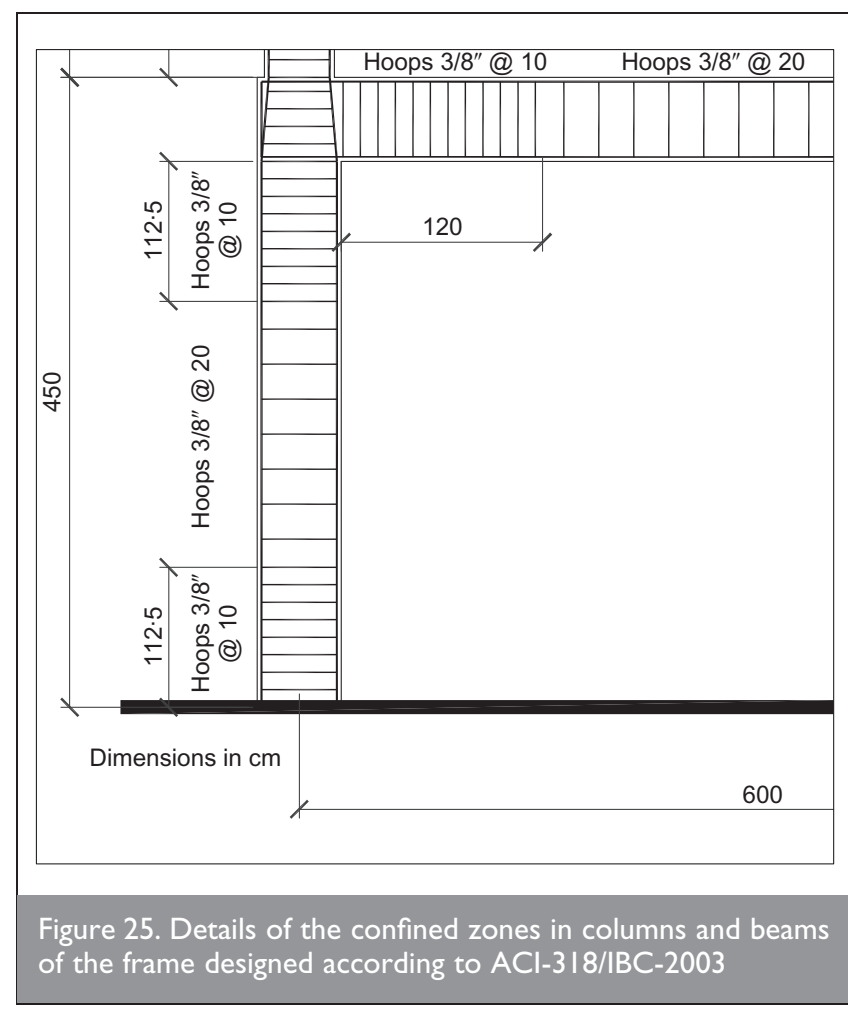

\section{REFERENCES}

1. Egozcue J. J., Barbat A. H., Canas J. A., Miquel J. and BANDA E. A method to estimate occurrence probabilities in low seismic activity regions. Earthquake Engineering and Structural Dynamics, 1991, 20, No. 1, 43-60.

2. Barbat A. H., Yépez Moya F. and CAnAs J. A. Damage scenarios simulation for risk assessment in urban zones. Earthquake Spectra, 1996, 2, No. 3, 371-394.

3. Barbat A. H., Pujades L. G. and Lantada N. Performance of buildings under earthquakes in Barcelona, Spain.
Computer-Aided Civil and Infrastructure Engineering, 2006, 21, No. 8, 573-593.

4. Barbat A. H., Pujades L. G. and Lantada N. Seismic damage evaluation in urban areas using the capacity spectrum method: application to Barcelona. Soil Dynamics and Earthquake Engineering, 2008, 28, Nos 10-11, 851865.

5. SEAOC. Vision 2000 Report on Performance Based Seismic Engineering of Buildings. Structural Engineers Association of California, Sacramento, California, 1995, Vol. I

6. Applied Technology Council (ATC). ATC-40: The Seismic Evaluation and Retrofit of Concrete Buildings. ATC, Redwood City, CA, 1996.

7. Federal EMERgency Management Agency. NEHRP Guidelines for the Seismic Rehabilitation of Buildings. FEMA 273-Provisions. FEMA 274-Commentary, Washington, DC, 1997.

8. BERTERO R. and BERTERO V. Performance-based seismic engineering: the need for a reliable conceptual comprehensive approach. Earthquake Engineering and Structural Dynamics, 2002, 31, No. 3, 627-652.

9. ElNASHAi A. and MwAFI A. Overstreght and force reduction factors of multistory reinforced-concrete buildings. Structural Design of Tall Buildings, 2002, 11, No. 5, 329351.

10. Fragiacomo M., Amadio C. and Rajgelu S. Evaluation of the structural response under seismic actions using nonlinear static methods. Earthquake Engineering and Structural Dynamics, 2006, 35, No. 12, 1511-1531.

11. ERBERIK A. and ElNASHAi A. Loss estimation analysis of flat-slab structures. Journal of Structural Engineering, 2006, 7, No. 1, 26-37.

12. Hueste M B. and BAi J.-W. Seismic retrofit of a reinforced concrete flat-slab structure: Part I -seismic performance evaluation. Engineering Structures, 2007, 29, No. 6, 11651177.

13. Uniform Building Code (UBC-97). International Building Conference of Building Officials, Whittier, California, 1997. 
14. International Building Code (IBC-2003). International Building Conference of Building Officials, Whittier, California, 2003.

15. Comité EuropéEn de Normalisation. Eurocode 8: Design of Structures for Earthquake Resistance. CEN, Brussels, 2003.

16. NORMA DE CONSTRUCCIÓN SISMORRESISTENTE. BOE No. 244. NSCE-2002. Madrid. 2002. Available online from: http:// www.proteccioncivil.org/centrodoc/legisla/NCSR-02.pdf.

17. Barbat A. H., Oller S. and Vielma J. C. Confinement and Ductility of Reinforced Concrete Buildings. ARCER, monograph No. 5, Madrid, 2007. In Spanish.

18. Vielma J. C., BARbAt A. H. and OlLeR S. Evaluación de la respuesta no lineal de edificios de hormigón armado con ductilidad limitada. Hormigón y Acero, 2008, 248, 55-60.

19. PARK R. State-of-the-art report: ductility evaluation from laboratory and analytical testing. Proceedings 9th WCEE, IAEE, Tokyo-Kyoto, 1988, VIII, 605-616.

20. COMISIÓN PERMANENTE DEL HORMIGÓN. Instrucción de hormigón estructura (EHE). Leynfor siglo XXI, Madrid, 1998.

21. American CONCRETE InSTITUTE. Building Code Requirements for Structural Concrete (ACI 318-05). ACI, Farmington Hills, Michigan, 2005, ACI Committee 318.

22. PLCd Manual. Non-linear thermo mechanic finite element oriented to PhD student education. Code developed at CIMNE, Barcelona, Spain, 2008.

23. Oller S. and BARBAT A. H. Moment-curvature damage model for bridges subjected to seismic loads. Computer Methods in Applied Mechanics and Engineering, 2006, 195, 4490-4511.

24. CAR E., OLLER S. and OÑATE E. A large strain plasticity for anisotropic materials: composite material application. International Journal of Plasticity, 2001, 17, No. 11, 1437 1463.

25. MAta P., Oller S. and BARBAt A. H. Static analysis of beam structures under nonlinear geometric and constitutive behaviour. Computer Methods in Applied Mechanics and Engineering, 2007, 196, Nos 45-48, 4458-4478.

26. Mata P., Oller S. and BARbat A. H. Dynamic analysis of beam structures under nonlinear geometric and constitutive behaviour. Computer Methods in Applied Mechanics and Engineering, 2008, 197, Nos 6-8, 857-878.

27. Oller S., OnATe E., Oliver J. and Lubliner J. Finite element non-linear analysis of concrete structures using a plasticdamage model. Engineering Fracture Mechanics, 1990, 35, Nos 1-3, 219-231.

28. Lubliner J., Oliver J., Oller S. and OÑATE E. A plastic- damage model for concrete. International Journal of Solids and Structures, 1989, 25, No. 3, 299-326.

29. Barbat A. H., Oller S., OnAte E. and HANGAnU A. Viscous damage model for Timoshenko beam structures. International Journal of Solids and Structures, 1997, 34, No. 30, 3953-3976.

30. Faleiro Freitas J., Oller S. and Barbat A. H. Plasticdamage seismic model for reinforced concrete frames. Computers and Structures, 2008, 86, Nos 7-8, 581-597.

31. OlLer S., CAR E. and Lubliner J. Definition of a general implicit orthotropic yield criterion. Computer Methods in Applied Mechanics and Engineering, 2003, 192, Nos 7-8, 895-912.

32. MartineZ X., Oller S., RASTellini F. and BARBAt A. H. A numerical procedure simulating RC structures reinforced with FRP using the serial/parallel mixing theory. Computers and Structures, 2008, 86, Nos 15-16, 1604-1618.

33. BAYRAK 0. and SHEIKH S. A. Plastic hinge analysis. Journal of Structural Engineering, 2001, 127, No. 9, 1092-100.

34. Spacone E. and El-TAWIL S. Nonlinear analysis of steel-concrete composite structures: State of the art. Journal of Structural Engineering, 2000, 126, No. 2, $159-168$.

35. Shao Y., Aval S. and Mirmiran A. Fiber-element model for cyclic analysis of concrete-filled fiber reinforced polymer tubes. Journal of Structural Engineering, 2005, 131, No. 2, 292-303.

36. Mander J. B., Priestley M. J. N. and PARK R. Observed stress-strain behaviour of confined concrete. Journal of Structural Engineering, 1988, 114, No. 8, 1827-1849.

37. HANGANU A., OÑATE E. and BARBAT A. H. A finite element methodology for local/global damage evaluation in civil engineering structures. Computers and Structures, 2002, 80, Nos 20-21, 1667-1687.

38. Barbat A. H., Oller S., OÑAte E. and HANGANU A. Viscous damage model for Timoshenko beam structures. International Journal of Solids and Structures, 1997, 34, No. 30, 3953-3976.

39. CAR E., Oller S. and OÑATE E. An anisotropic elastoplastic constitutive model for large strain analysis of fiber reinforced composite materials. Computer Methods in Applied Mechanics and Engineering, 2000, 185, Nos 2-4, 245-277.

40. FAJFAR P. A Nonlinear analysis method for performance based seismic design. Earthquake Spectra, 2000, 16, No. 3, 573-591.

\section{What do you think?}

To comment on this paper, please email up to 500 words to the editor at journals@ice.org.uk

Proceedings journals rely entirely on contributions sent in by civil engineers and related professionals, academics and students. Papers should be 2000-5000 words long, with adequate illustrations and references. Please visit www.thomastelford.com/journals for author guidelines and further details. 